\title{
地中温度の計測結果を用いた 不飽和地盤の水分変動評価手法の提案
}

\author{
里見 知昭 $1 \cdot$ 酒匂 一成 $2 \cdot$ 安川 郁夫 $3 \cdot$ 深川 良一 4 \\ 1学生会員 立命館大学大学院 理工学研究科 博士課程後期課程 (广525-8577 滋賀県草津市野路東1-1-1) \\ E-mail : rd005010@se.ritsumei.ac.jp \\ 2正会員 立命館大学准教授 グローバル・イノベーション研究機構 (†525-8577 滋賀県草津市野路東1-1-1) \\ E-mail : kaz-sako@fc.ritsumei.ac.jp \\ 3フェロー会員 立命館大学 総合理工学研究機構 客員研究員 (†525-8577 滋賀県草津市野路東1-1-1) \\ E-mail : 552ikuo@fc.ritsumei.ac.jp \\ 4フェロー会員 立命館大学教授 理工学部 都市システム工学科 (†525-8577 滋賀県草津市野路東1-1-1) \\ E-mail : fukagawa@se.ritsumei.ac.jp
}

\begin{abstract}
本論文では，降雨や日射によって地盤内の水分（間隙水圧，体積含水率）や温度が変化する特性に注目 し, 地中温度計測による不飽和地盤の水分変動評価手法を提案した。 その提案手法において「熱一水分特 性曲線」を定義し, 提案手法の妥当性を検証するために降雨による室内土槽試験を行い, 間隙水圧と地中 温度を計測した。その結果, 雨水が地盤内に浸透するとともに地中温度は水温に近づくことが確認され, 地盤内の水分が急増したときの挙動に対して提案手法による算定結果は試験結果とほぼ一致した. したが って，地中温度計測による本手法は経過時間に対して温度が変化する範囲では有用であることが示された。
\end{abstract}

Key Words : ground tempareture, soil moisture characteristic curve, one-dimensional heat equation, FDM, soil modeling test

\section{1. はじめに}

近年わが国では，梅雨期や台風襲来期の大雨による斜 面災害が多発している。降雨に対する斜面災害を予知し て被害を減らすためには，斜面防災対策を講じる必要が ある，従来は主に降雨量に基づいて斜面の危険度を評価 し，避難勧告を発令することに重点が置かれてきた。こ の評価方法は，広域を評価対象とする場合には有効であ るが，地域ごとの地形や地質に対応したパラメータを設 定することは困難であるため，一般には「花崗岩」に対 応するパラメータを適用している ${ }^{1)}$ ，その結果，降雨時 斜面の危険度を判断する際に空振りが生じるおそれがあ るため, 実際に地盤内の水分変動を計測して把握するこ とが望ましいと考えられる. その地盤内の水分変動を計 測する方法として, テンシオメータ法, 誘電率法, ヒー トプローブ法などが挙げられる，これらの方法は，地盤 内水分の変動に伴って, 圧力センサの出力電圧, 比誘電 率，そして熱伝導率などが変化する関係を利用しており， 以下，各計測方法の特徵を簡単に述べる.

テンシオメータ法は, 間隙水圧の計測方法として一般
に広く使われているが，降雨回数が少なく地盤内の乾燥 状態が続くと, 計測機器の脱気水が抜けて計測できない という問題がある。誘電率法の場合，比誘電率が温度や 乾燥密度などに影響するため, これらの因子との関係を 表した実験式 ${ }^{2)}$ が提案されている. そして, ヒートプロ 一ブ法は，土中水が増えると熱伝導率が大きくなるとい う特徴を利用し，プローブにヒータによる熱源を与えて センサの温度変化を測定して熱伝導率を求めている. こ の方法を使って含水量を計測するためには, 熱伝導率と 含水量の関係をあらかじめ求めておく必要がある ${ }^{3)}$.

本研究では, 以上の種々の計測方法の特徵と降雨や日 射によって地盤内の水分や温度が変化するという特性を 考慮して，ヒートプローブ法の熱伝導率と含水量の関係 を応用した新しい方法を提案する. これは従来のヒート プローブ法と異なり, 熱源を必要とせず温度変化のみを 使って地盤内の水分変動を評価する方法である. この方 法が適用できると, 計測機器のメンテナンスの軽減や設 置コストの削減に期待できる可能性がある，本論文では， 提案手法の有効性を検証するために降雨による室内土槽 試験を行い，試験結果と提案手法による計算結果を比 
較・検討する。そして，提案手法を現地に適用した場合 を想定し, 提案手法の適用範囲などについて考察する.

\section{2. 提案手法の概要}

「1.はじめに」でも述べたように，本研究の目的は， 熱源を使わずに地中温度の変化のみで地盤内の水分変動 を評価することであり，地中温度の計測結果から水分変 動を評価するフローを図-1に示す．図-1に基づいて評価 手順を説明する。はじめに，地中温度を計測し，1次元 熱伝導方程式（陽解法を用いて有限差分）に地中温度の 計測結果を代入して, 評価地点の熱拡散係数を算出する

（図-1の[1]）。その後，あらかじめ室内モデル試験から 得られた結果を使って，「熱拡散係数〜体積含水率」関 係を求める（図-1の[2]）。この関係式を使って，地盤内 の水分変動を把握することができる．ここで，「体積含 水率〜圧力水頭（間隙水圧）」関係を表した水分特性曲 線（図-1の[3]）を「熱拡散係数〜体積含水率」関係と組 み合わせると「熱拡散係数〜水分特性曲線」関係が得ら れ，その関係式を「熱一水分特性曲線 : Heat-soil moisture characteristic curve」と定義する．以下，図-1の[1]，[2]，[3] について具体的に説明する.

\section{（1）1次元熱伝導方程式を用いた熱拡散係数の算定}

式(1)に 1 次元熱伝導方程式を示し，式(1)の「熱拡散係 数 $a 」$ は式(2)のように表される.

$$
\begin{gathered}
\frac{\partial T}{\partial t}=a \frac{\partial^{2} T}{\partial z^{2}} \\
a=\frac{\lambda}{C}=\frac{\lambda}{\rho \cdot c}
\end{gathered}
$$

ここで， $T$ は地中温度 $[\mathrm{K}], t$ は時間 $[\mathrm{sec}], \quad z$ は 位置 $[\mathrm{m}] ， a$ は熱拡散係数 $\left[\mathrm{m}^{2} / \mathrm{sec}\right] ， \lambda$ は熱伝導率 $[\mathrm{W} /(\mathrm{m} \cdot \mathrm{K})], C$ は体積比熱 $\left[\mathrm{kJ} /\left(\mathrm{m}^{3} \cdot \mathrm{K}\right)\right], \quad \rho$ は密度 $\left[\mathrm{kg} / \mathrm{m}^{3}\right], c$ は質量比熱 $[\mathrm{kJ} /(\mathrm{kg} \cdot \mathrm{K})]$ を表す。なお, 式(1)は水や空気のフラックスによる影響は考慮してい ない.しかし，本論文では温度計測結果から熱拡散係数 を算定して地盤内の水分変動を簡易に評価することが目 的であるため，式(1)を不飽和地盤内の熱移動を表現す るための基礎式とした.

次に, 図-2 の陽解法を使って式(1)を有限差分すると

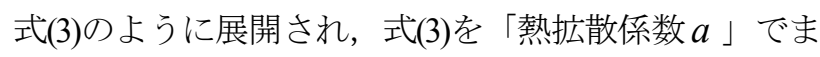
とめると式(4)のように表される．本論文で土の熱的性 質の特性值として「熱拡散係数 $a 」 に$ 注目したのは,

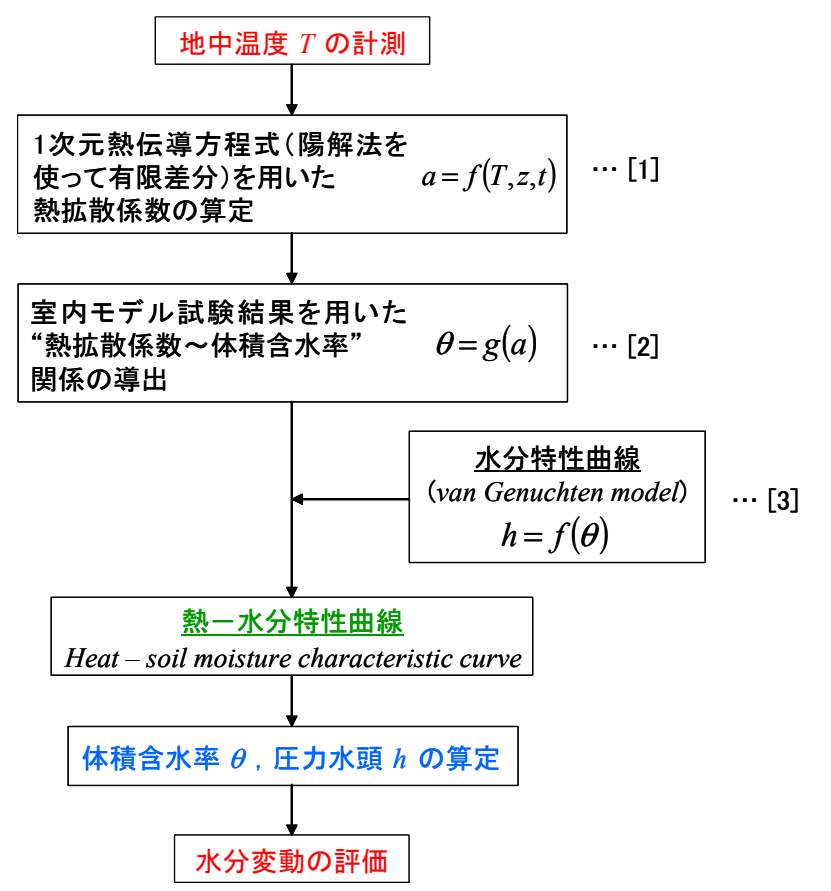

図-1＼cjkstart提案手法による評価フロー

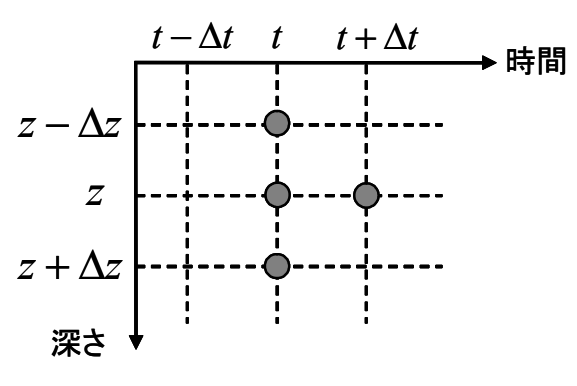

$\bigcirc:$ 熱拡散係数の計算に使う温度

図-2 陽解法

式(4)に示すとおり深さ（空間）と時間に対する地中温 度の計測結果のみで「熱拡散係数 $a$ 」を求めることが できるからである.なお，図-2に示す4つのプロットは 熱拡散係数の計算に使う地中温度である.

$$
\begin{gathered}
\frac{T(z, t+\Delta t)-T(z, t)}{\Delta t}=a \cdot \frac{T(z+\Delta z, t)-2 T(z, t)+T(z-\Delta z, t)}{\Delta z^{2}} \\
a=\frac{\Delta z^{2}}{\Delta t} \cdot \frac{T(z, t+\Delta t)-T(z, t)}{T(z+\Delta z, t)-2 T(z, t)+T(z-\Delta z, t)}
\end{gathered}
$$

ここで, $T(z, t)$ は深さ $z$, 時間 $t$ の地中温度, $\Delta z$ は温 度計測した2点間の距離（空間増分）， $\Delta t$ は計測時間の 間隔（時間増分）を表す。

\section{（2）「熱拡散係数〜体積含水率」関係式の導出}

熱拡散係数と体積含水率の関係式を導くため, 熱伝導 
表-1＼cjkstart試料の基本物性值

\begin{tabular}{ll|l}
\hline 土粒子密度 & $\rho_{s}\left[\mathrm{~g} / \mathrm{cm}^{3}\right]$ & 2.628 \\
\hline 最小密度 & $\rho_{d \min }\left[\mathrm{g} / \mathrm{cm}^{3}\right]$ & 1.297 \\
\hline 最大密度 & $\rho_{d \max }\left[\mathrm{g} / \mathrm{cm}^{3}\right]$ & 1.672 \\
\hline 最小間隙比 & $e_{\min }$ & 0.572 \\
\hline 最大間隙比 & $e_{\max }$ & 1.026 \\
\hline 最大乾燥密度 & $\rho_{d \max }\left[\mathrm{g} / \mathrm{cm}^{3}\right]$ & 1.937 \\
\hline 最適含水比 & $w_{\text {opt }}[\%]$ & 11.5 \\
\hline
\end{tabular}

による室内モデル試験の結果と体積比熱の理論式を使う. 本節では，試験結果と体積比熱の理論式について述べる.

\section{a）熱伝導による室内モデル試験}

本試験は，地盤内の水分量の違いが地盤内の熱伝導特 性にどの程度影響するかを検証し，地盤内の水分量と熱 伝導率の関係を求めるために実施する。試料は信楽産山 砂（まさ土）を使用し, 試料の基本物性值, 粒径加積曲 線, 締固め曲線をそれぞれ表-1, 図-3, 図-4に示す。なお, 締固め試験はJIS A 1210 のA-a法（乾燥法・繰返し法）で 実施した. 土の水分量は3パターン（含水比 : 5.3, 15.4, $35.9 \%$ ）を想定し，試料はあらかじめ含水比調整を行っ てから供試体を作製した。ただし，含水比 $35.9 \%$ （飽和 度100\%）の供試体に関しては，供試体を作製した後， 底面から湿潤させている. 図-5に試験の概要（計測機器 の設置位置) を示す．モデル地盤はアクリル製の円筒カ

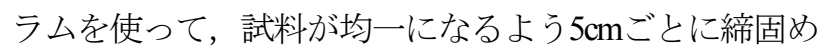
て作製した。また，地表面からのみ熱伝導を行うために 円筒力ラムの周りに断熱シートを巻き，さらに地表面に は水分が蒸発しないようにラップを敷いた。底面は非排 水条件である. 表-2に示す条件で試験を行い，八ロゲン ヒーターを熱源として熱を与える時間と与えない時間を それぞれ60分と設定した。 なお，Case2は含水比を $15.4 \%$ として供試体を作製したものの，他のケースの乾燥密度 と異なっていることを断った上で，試験結果を整理する.

本論文では，含水比 $15.4 \%$ の試験結果のみを示し，試 験中は土槽内の含水比が一様であると仮定して整理して いる. 図-6は各深さの温度，図-7は各深さの熱流の時系 列変化である. 本試験より，表-3と図-8に示すような地 盤内の水分量と熱伝導率の関係が得られ，水分量の違い が熱の伝播特性に影響を及ぼしていると判断される。な お，Case2は想定した乾燥密度よりも大きく間隙比は小 さくなったため, 実際の熱伝導率よりも大きな值が得ら れた可能性があり, 乾燥密度を他のケースと同值と仮定 した場合の熱伝導率は0.504W/(m・K)であった。ここで， 比熱が空気よりも水のほうが大きいことを考慮すると4), 含水状態が等しく間隙比が小さい場合は熱が伝わりやす

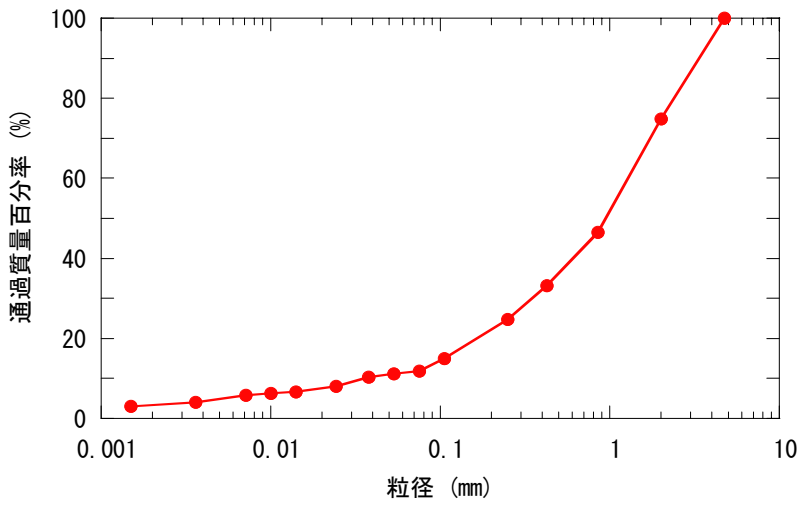

図-3＼cjkstart粒径加積曲線

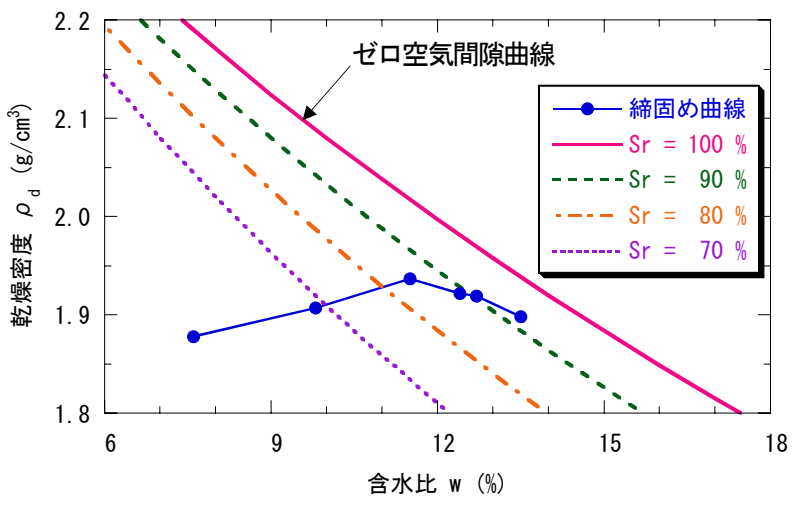

図-4 締固め曲線

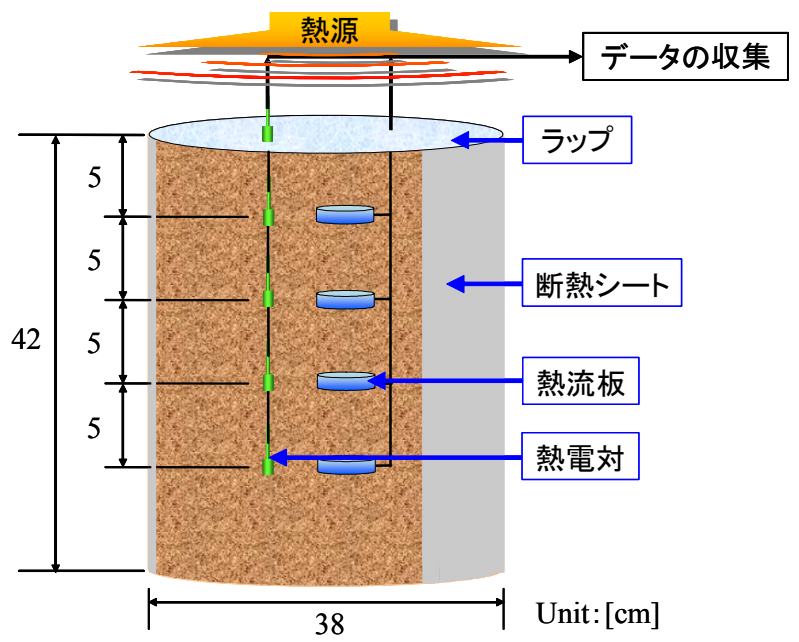

図-5 モデル試験の概要（計測機器の設置位置）

表-2 試験条件

\begin{tabular}{ll|c|c|c}
\hline & & Case1 & Case2 & Case3 \\
\hline \hline 土粒子密度 & $\rho_{s}\left[\mathrm{~g} / \mathrm{cm}^{3}\right]$ & \multicolumn{3}{|c}{2.628} \\
\hline 乾燥密度 & $\rho_{d}\left[\mathrm{~g} / \mathrm{cm}^{3}\right]$ & 1.367 & 1.700 & 1.367 \\
\hline 間隙比 & $e$ & 0.922 & 0.546 & 0.922 \\
\hline 含水比 & $w[\%]$ & 5.3 & 15.4 & 35.9 \\
\hline 体積含水率 & $\theta$ & 0.072 & 0.262 & 0.491 \\
\hline
\end{tabular}




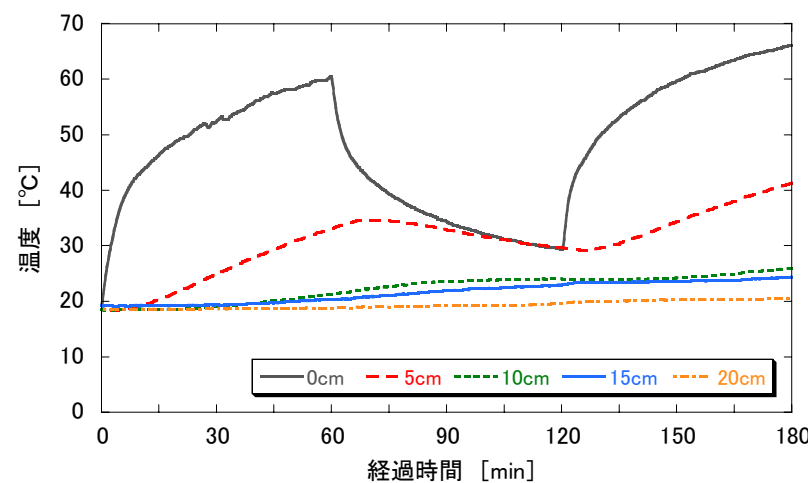

図-6＼cjkstart温度の時系列変化（ $w=15.4 \%)$

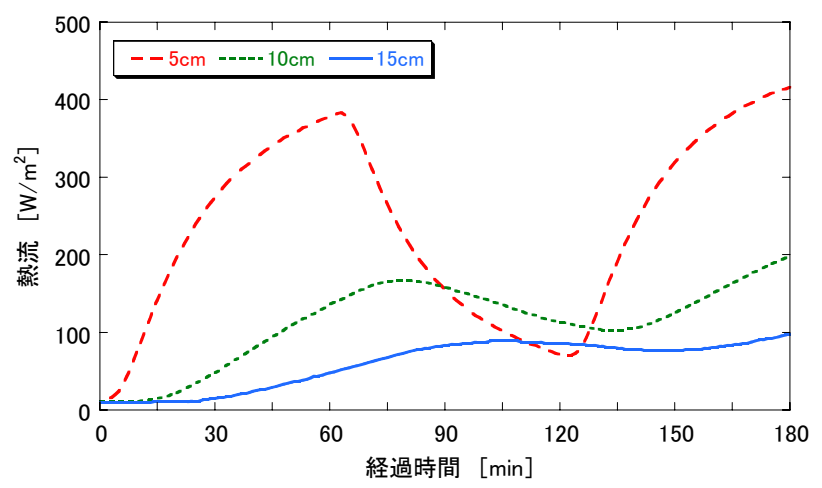

図-7 熱流の時系列変化 $(w=15.4 \%)$

いことを意味している結果であると解釈できる.

地盤内の水分量と熱伝導率の関係を具体的に表現する ために，様々な理論式5), の実験式7が報告されている.

本論文では，文献のの実験結果による近似式に基づいて， 地盤内の水分量と熱伝導率の関係を式(5)のように一次 式で近似した．式(5)の $\beta, \gamma$ は近似直線の傾きと切片で ある.なお，熱伝導率の算出には文献8)の「位相法」を 用いた。

$$
\lambda=2.5506 \theta+0.0995,[\lambda=\beta \theta+\gamma]
$$

\section{b）体積比熱の理論式}

一般に，土は固相・液相・気相の三相構造であり，式 (2)の体積比熱 $C$ は式(6)のように表される. 式(6)の添え 字 $s, w, a$ は，それぞれ土粒子，水，空気を意味する.

$$
\begin{aligned}
C & =\rho \cdot c \\
& =\sum(\text { soil particle }+ \text { water }+ \text { air }) \\
& =\theta_{s} \rho_{s} c_{s}+\theta_{w} \rho_{w} c_{w}+\theta_{a} \rho_{a} c_{a} \\
& =\left\{\rho_{d} c_{s}+\left(1-\frac{\rho_{d}}{\rho_{s}}\right) \rho_{a} c_{a}\right\}+\left(\rho_{w} c_{w}-\rho_{a} c_{a}\right) \cdot \theta
\end{aligned}
$$

ここで， $\rho_{d}$ は乾燥密度 $\left[\mathrm{kg} / \mathrm{m}^{3}\right] ， \theta$ は体積含水率, $\rho$ は密度 $\left[\mathrm{kg} / \mathrm{m}^{3}\right], c$ は質量比熱 $[\mathrm{kJ} /(\mathrm{kg} \cdot \mathrm{K})]$ を表す。

以上より，式(5)と式(6)を式(2)に代入すると熱拡散係 数と体積含水率の関係が成立し, 式(7)や式(8)のように
表-3 試験結果

\begin{tabular}{c|c|c|c}
\hline & Case1 & Case2 & Case3 \\
\hline \hline 体積含水率 $\theta$ & 0.072 & 0.262 & 0.491 \\
\hline $\begin{array}{c}\text { 熱伝導率 } \lambda \\
{[\mathrm{W} /(\mathrm{m} \cdot \mathrm{K})]}\end{array}$ & 0.361 & 0.627 & 1.415 \\
\hline
\end{tabular}

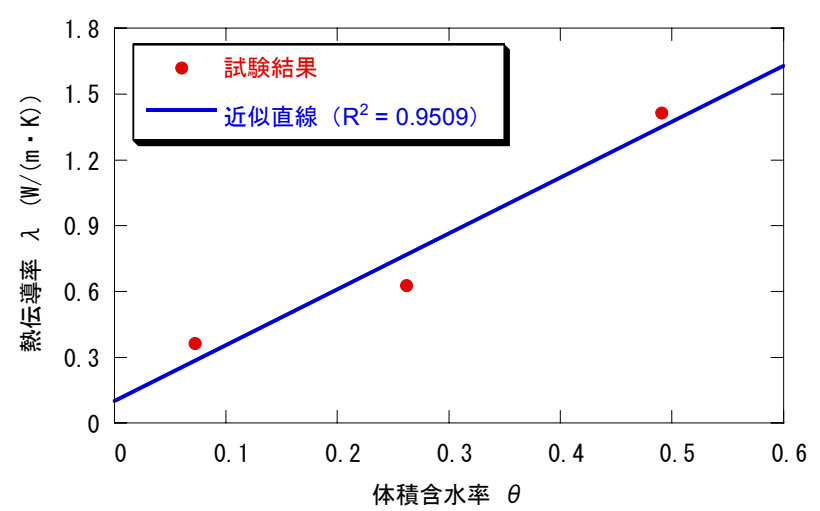

図-8 体積含水率～熱伝導率

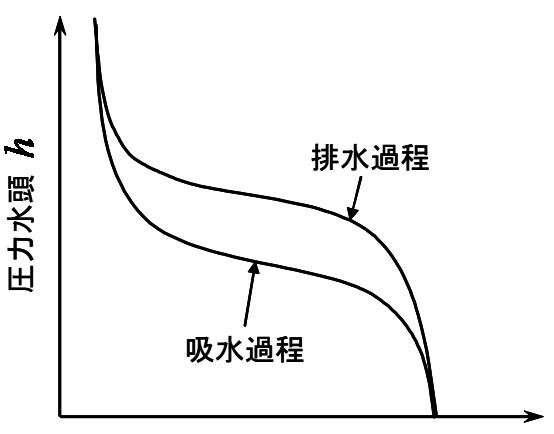

体積含水率 $\theta$

図-9 地盤内の浸透特性

表される。式(8)の右辺から分かるように，「熱拡散係 数 $a 」$ 以外の物理量は室内試験の結果や文献から得るこ とができる，つまり，地中温度の計測結果のみを使うこ とで，体積含水率が求まることを意味している.

$$
\begin{gathered}
a=\frac{\lambda}{C}=\frac{\beta \theta+\gamma}{\left\{\rho_{d} c_{s}+\left(1-\frac{\rho_{d}}{\rho_{s}}\right) \rho_{a} c_{a}\right\}+\left(\rho_{w} c_{w}-\rho_{a} c_{a}\right) \cdot \theta} \\
\theta=\frac{\gamma-\left\{\rho_{d} c_{s}+\left(1-\frac{\rho_{d}}{\rho_{s}}\right) \rho_{a} c_{a}\right\} \cdot a}{\left(\rho_{w} c_{w}-\rho_{a} c_{a}\right) \cdot a-\beta}
\end{gathered}
$$

\section{（3）「体積含水率～圧力水頭」関係の導出}

土の水分特性（保水性や吸・排水性など）の影響を受 ける不飽和土の浸透特性を検討寸るためには，その浸透 特性の影響を表した図-9のような体積含水率と圧力水頭 
の関係（水分特性曲線）を考慮する必要がある。なお， 本論文では，間隙水圧を水頭に換算した值を圧力水頭と 定義する. この曲線の形状は土の種類によって異なるた め，水分特性を具体的に把握して評価する際には，それ ぞれの土に対する水分特性を定式化する必要がある。本 論文では，図-9の排水や吸水過程で生じるヒステリシス を考慮せず各物理量が1対1で対応するものとして，van Genuchtenが提案した式（式(9), 式(10)参照) 9)を採用した. 式(9)の「 $m=1-1 / n 」$ は, Mualemが体積含水率から不飽 和透水係数を算出するために提案した式をclosed formで 表現するために使った条件式である ${ }^{10)}$.

$$
\begin{aligned}
& \Theta=\frac{\theta-\theta_{r}}{\theta_{s}-\theta_{r}}=\frac{1}{\left(1+|\alpha h|^{n}\right)^{n}} \\
& m=1-\frac{1}{n} \\
& h=\frac{1}{\alpha} \cdot\left[\left(\frac{\theta_{s}-\theta_{r}}{\theta-\theta_{r}}\right)^{\frac{n}{n-1}}-1\right]^{n}
\end{aligned}
$$

ここで， $\Theta$ は有効飽和度， $\theta_{s}$ は飽和体積含水率， $\theta_{r}$ は残留体積含水率, $h$ は圧力水頭 $[\mathrm{cm}], \alpha, n$ はスケ ーリングパラメータ $[\alpha: 1 / \mathrm{cm}, n$ : 無次元 $]$ を表す. パラメータの設定には，2 次元土中水分移動予測プログ ラムHYDRUS-2D ${ }^{11)} の$ Neural Network Predictionを適用し，入 力情報に「粒径分布，土の乾燥密度」を用いた。

\section{3. 熱一水分特性曲線}

本論文では，式(8)の「熱拡散係数〜体積含水率」関 係，式(8)と式(10)を組夕合わせた式(11)の「熱拡散係数 ～圧力水頭」関係をまとめて「熱一水分特性曲線」と定 義する. 一例として, 提案手法の妥当性を検証するため の試験（5. 室内土槽試験 I）で使用した設定パラメー 夕 4), 12) (表-4 参照) による「熱一水分特性曲線」を示す. 図-10 は「熱拡散係数〜体積含水率」関係，図-11 は 「熱拡散係数〜圧力水頭」関係を表している.

$$
\begin{aligned}
& h=\frac{1}{\alpha} \cdot\left[\left\{\frac{D\left(\theta_{s}-\theta_{r}\right)}{E-F \theta_{r}}\right\}^{\frac{n}{n-1}}-1\right]^{n} \\
& D=\left(\rho_{w} c_{w}-\rho_{a} c_{a}\right) \cdot a-\beta \\
& E=\gamma-\left\{\rho_{d} c_{s}+\left(1-\rho_{d} / \rho_{s}\right) \rho_{a} c_{a}\right\} \cdot a \\
& F=\left(\rho_{w} c_{w}-\rho_{a} c_{a}\right) \cdot a-\beta
\end{aligned}
$$

\begin{tabular}{|c|c|c|}
\hline \multicolumn{2}{|c|}{ 乾燥密度 $\quad \rho_{d}\left[\mathrm{~g} / \mathrm{cm}^{3}\right]$} & 1.371 \\
\hline \multirow{3}{*}{$\begin{array}{l}\text { 密度 } \\
{\left[\mathrm{g} / \mathrm{cm}^{3}\right]}\end{array}$} & 土粒子 $\rho_{s}$ & 2.628 \\
\hline & $\rho_{w}$ & 1.000 \\
\hline & 空気 $\rho_{a}$ & 0.001293 \\
\hline \multirow{3}{*}{$\begin{array}{c}\text { 質量比熱 } \\
{[\mathrm{kJ} /(\mathrm{kg} \cdot \mathrm{K})]}\end{array}$} & 土粒子 $c_{s}$ & 0.84 \\
\hline & $c_{w}$ & 4.18 \\
\hline & 空気 $c_{a}$ & 1.00 \\
\hline \multirow{2}{*}{$\begin{array}{c}\theta \sim \lambda \\
\text { (近似直線) }\end{array}$} & 傾き $\quad \beta$ & 2.5506 \\
\hline & 切片 $\gamma$ & 0.0995 \\
\hline \multicolumn{2}{|c|}{ 残留体積含水率 $\theta_{r}$} & 0.0494 \\
\hline \multicolumn{2}{|c|}{ 飽和体積含水率 $\theta_{S}$} & 0.4271 \\
\hline \multirow{2}{*}{$\begin{array}{c}\text { スケーリング } \\
\text { パラメータ }\end{array}$} & $n$ & 2.2649 \\
\hline & $\alpha[1 / \mathrm{cm}]$ & 0.0372 \\
\hline 飽和透水係数 & $k_{s}[\mathrm{~cm} / \mathrm{sec}]$ & $4.33 \times 10^{-3}$ \\
\hline
\end{tabular}

表-4 設定パラメータ

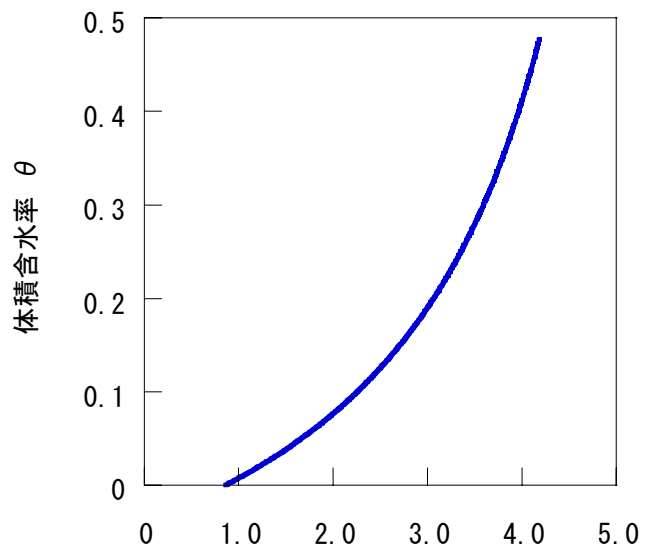

熱拡散係数 $\mathrm{a}\left(\times 10^{-7}\right)\left(\mathrm{m}^{2} / \mathrm{sec}\right)$

図-10 熱拡散係数 体積含水率

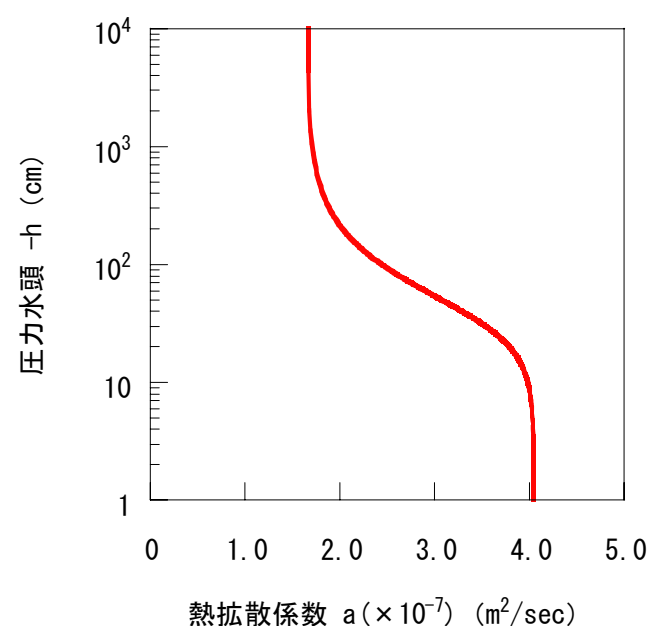

図-11 熱拡散係数〜圧力水頭 


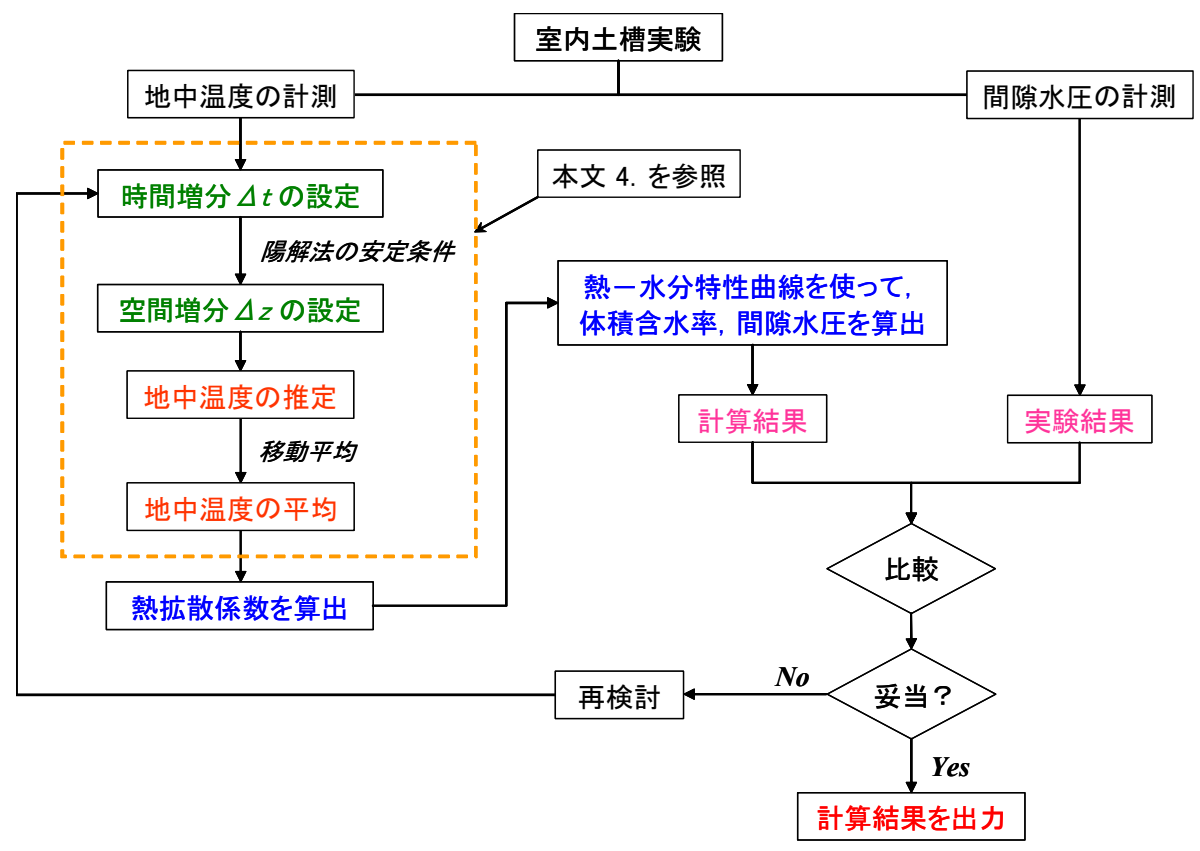

図-12 評価フロー

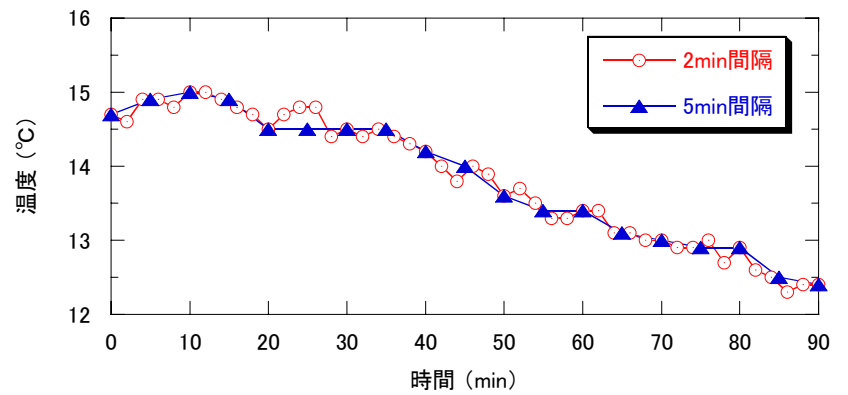

図-13 2min，5min 閒隔の温度変化（計測結果）

\section{4. 熱拡散係数の算定に関する設定および条件}

本章では，図-1の「地中温度の計測」から「熱拡散係 数の算定」までの計算過程を詳しく述べる.この計算過 程を表したフローは図-12の点線で囲んだ部分であり，

「時間増分 $\Delta t$ と空間増分 $\Delta z$ の設定」，「地中温度の推 定」, そして「地中温度の平均」を具体的に説明する.

\section{（1）時間増分と空間増分の設定}

時間増分 $\Delta t$ と空間増分 $\Delta z$ は式(4)の熱拡散係数を算出 する際に重要な值となるため, その設定方法を検討する.

\section{a) 時間増分}

一例として，提案手法の妥当性を検証するための試験

（5. 室内土槽試験 I）で計測した「深さ $10 \mathrm{~cm} の$ 地中温 度」の結果を使って, 時間増分 $\Delta t$ の設定を説明する. この試験は 1 分間隔で計測しており, 計測データを 2 分 間隔および 5 分間隔で抽出すると図-13 のようになる. 図-13の 2 分間隔で計測した場合，温度は経過時間に対 して細かく変動し，5 分間隔での計測結果よりもデータ
に乱れ（振幅）が生じやすい傾向にあり，データの乱れ は本研究で使用した熱電対の精度 $\left( \pm 0.5^{\circ} \mathrm{C}\right)$ によるも のと推測される.したがって，データの乱れが熱拡散係 数の計算結果に影響を与える可能性があるため, 計測間 隔はある程度長く設定することが望ましい．また，計測 間隔を明確かつ容易に設定管理するため，本論文では時 間増分を 5 分に設定して熱拡散係数を算出する.

\section{b) 空間増分}

陽解法を使って 1 次元熱伝導方程式（式(3)参照）を式 (12)のように整理すると, 左辺が正值の場合は少なくと も右辺第 2 項は正值となる必要があり, 右辺第 2 項の括 弧内は安定条件である式(13)を満たさなければならない.

$$
\begin{aligned}
& T(z, t+\Delta t)= a \frac{\Delta t}{\Delta z^{2}}\{T(z+\Delta z, t)+T(z-\Delta z, t)\} \\
&+\left(1-2 a \frac{\Delta t}{\Delta z^{2}}\right) T(z, t) \\
& 1-2 a \frac{\Delta t}{\Delta z^{2}} \geq 0 \quad \therefore \quad 0 \leq a \leq \frac{\Delta z^{2}}{2 \Delta t}
\end{aligned}
$$

ここで，式(13)の「熱拡散係数 $a 」 に$ 関して図-14 に 示す「熱拡散係数の最小值 $a_{\min }$, 最大值 $a_{\max } 」$ までを 評価範囲とすると（ $a_{\min } \leq a \leq a_{\max } ）$ ，式(14)のような 関係が得られる。そして，式(14)の「熱拡散係数の平均 值」を使って空間増分 $\Delta z$ を設定すると, 式(15)のように 表される.

$$
a_{\min } \leq \frac{\Delta z^{2}}{2 \Delta t} \leq a_{\max }
$$




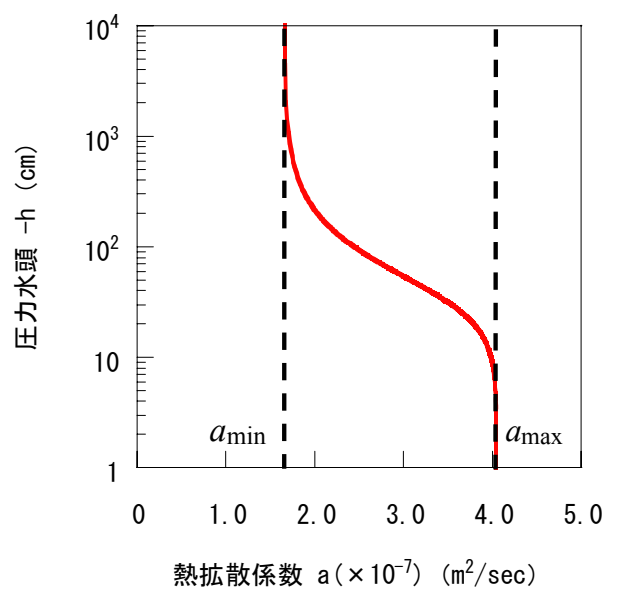

図-14＼cjkstart熱拡散係数の評価範囲

$$
\frac{\Delta z^{2}}{2 \Delta t}=\frac{a_{\min }+a_{\max }}{2} \therefore \Delta z=\sqrt{\left(a_{\min }+a_{\max }\right) \Delta t}
$$

\section{（2）地中温度の推定}

式(15)の空間増分 $\Delta z$ を使って評価地点の熱拡散係数 を算出するためには，評価地点からそれぞれ空間増分 $\Delta z$ だけ離れた地中温度を推定する必要があり，図-15 に示す方法を使う。今回は $10 \mathrm{~cm}$ 間隔に設置した温度計 (熱電対) の計測結果を使用し，温度分布は線形である と仮定して地中温度を推定する。ここで，温度分布を線 形と仮定したのは，熱フラックスと温度との関係である 式(16)のフーリエ則に基づくと， 2 点間の温度変化で表 されるものとして解釈できるからである.

$$
q=-\lambda \frac{d T}{d z}=-\lambda \frac{T(z+\Delta z)-T(z)}{d z}
$$

ここで， $q$ は熱フラックス $\left[\mathrm{W} / \mathrm{m}^{2}\right] ， \lambda$ は熱伝導率

$[\mathrm{W} /(\mathrm{m} \cdot \mathrm{K})], d T / d z \quad[\mathrm{~K} / \mathrm{m}]$ は深さ $z$ 方向に対する 温度勾配を表す。

\section{（3）地中温度の平均}

地中温度の計測に対して時間間隔 $\Delta t$ が短くなるほど, 計測データに乱れが生じやすいことを「4. (1) a) 時間増 分」で述べた。一方，時間間隔 $\Delta t$ を長く設定すると， 図-16 に示す点線の囲み部分のような局所的な変化が生 じやすい傾向になり，この傾向が熱拡散係数の計算結果 に影響を与える可能性がある。この局所的な変化を緩和 する方法として，移動平均（Moving Average）を適用す ることを考えた，移動平均とは，図-17 に示すように一 定幅のデータの傾向を捉えつつ平均值を連続して計算で きるという特徵をもつ。本論文では，式 (17)の単純移動 平均（Simple Moving Average）を採用する. 式(17)の $T_{t-1}$, $T_{t}, T_{t+1}$ は時間 $t-1, t, t+1$ の計測值である.

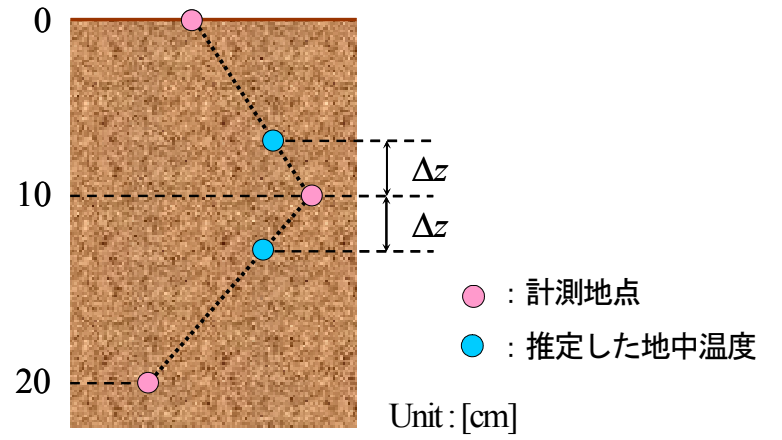

図-15＼cjkstart温度分布による地中温度の推定

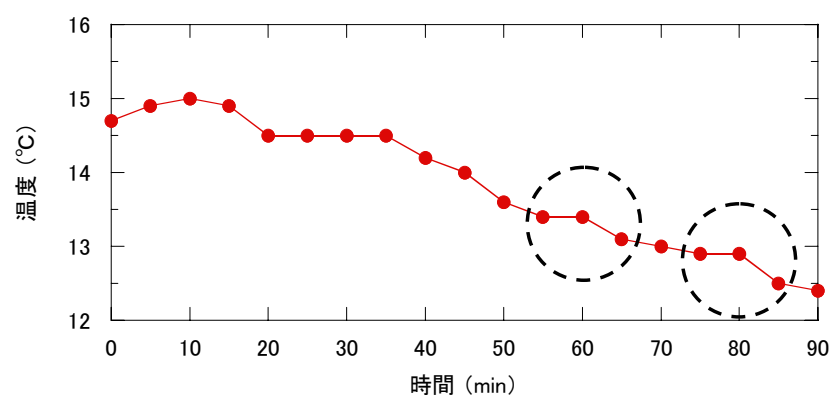

図-16 計測結果（図-13の 5min 間隔

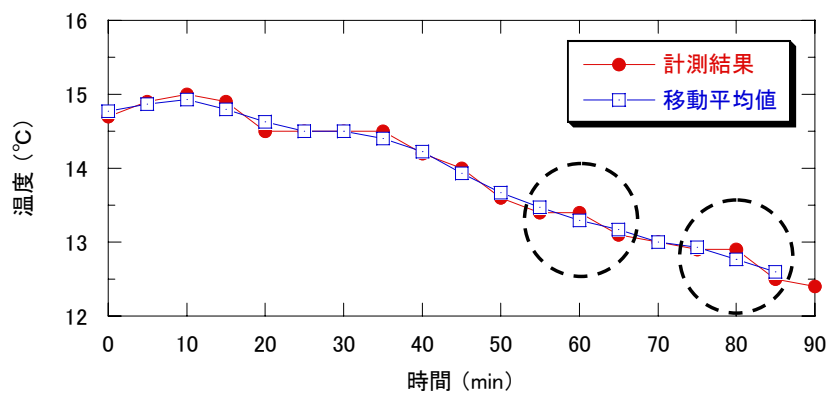

図-17計測結果と移動平均值

$$
\bar{T}=\frac{1}{3}\left(T_{t-1}+T_{t}+T_{t+1}\right)
$$

\section{（4）熱拡散係数の算定結果の条件範囲}

熱拡散係数の算定範囲として，計測結果から算出した 熱拡散係数がその最小值（ $a_{\min } ）$ より小さくなった場 合は「最小值： $a_{\min } 」$ を採用する。一方，計測結果か ら算出した熱拡散係数がその最大值（ $a_{\max }$ ) より大き くなった場合は「最大值： $a_{\max } 」$ を採用する.

\section{5. 室内土槽試験 I}

本試験は，地中温度の計測によって地盤内の水分変動 を評価できるか検証するために行う。今回用いた試料は 信楽産山砂（まさ土）で，熱伝導による室内モデル試験 の試料と同様である. 図-18 に示すように，地中温度を 計測するために熱電対（深さ：0,10,20cm），間隙水圧 
(圧力水頭) を計測するために埋設型圧力変換器付きテ ンシオメータ（深さ：10,20cm），そして体積含水率を 計測するために ADR センサ（深さ : $20 \mathrm{~cm}$ ）を用いた. 計測間隔は 1 分とし, 深さ $20 \mathrm{~cm}$ のテンシオメータと ADR センサが反応し始めてから深さ $20 \mathrm{~cm}$ が飽和状態に 限りなく近づいたときを試験終了とした。表-5に試験 条件，表-6に室内・降雨条件を示す.

\section{（1）試験結果}

図-19 は深さ $10,20 \mathrm{~cm}$ の間隙水圧と深さ $20 \mathrm{~cm}$ の体積 含水率の変化を, 図-20 は室内と各深さの地中温度の変 化を表しており，降雨浸透による地盤内の水分変動，熱 伝導と水分移動による地中温度の変化（熱輸送）につい て考察する. なお，本試験は供試体作製が完了してから すぐに開始しており, 計測深度に対して初期の地中温度 が異なっているのは，供試体の作製によって生じた温度 差であると推測される.

\section{a）降雨浸透による地盤内の水分変動}

深さ $10 \mathrm{~cm}$ の間隙水圧は降雨開始から約 36 分後, 深さ $20 \mathrm{~cm}$ は深さ $10 \mathrm{~cm}$ が変化してから約 40 分後に急増し, 変化した後は一定值を推移している. 一方, 深さ $20 \mathrm{~cm}$ の体積含水率は，深さ $20 \mathrm{~cm}$ の間隙水圧とほぼ同時刻に 変化している，つまり，間隙水圧や体積含水率を計測す ることで，不飽和地盤内の浸透過程を良好に把握できる と判断される.

\section{b）熱伝導と水分移動による温度変化（熱輸送）}

降雨開始から地表面の温度が低下し，試験終了時には 水温に近づいた. また, 深さ $10 \mathrm{~cm}$ の間隙水圧が正圧に

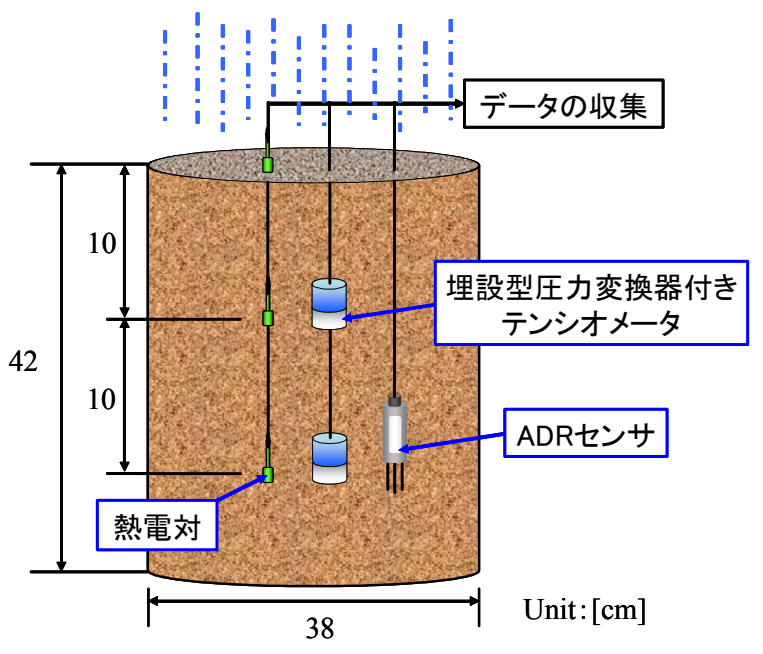

図-18 土槽試験の概要

表-5 試験条件

\begin{tabular}{ll|c}
\hline 土粒子密度 & $\rho_{s}\left[\mathrm{~g} / \mathrm{cm}^{3}\right]$ & 2.628 \\
\hline 乾燥密度 & $\rho_{d}\left[\mathrm{~g} / \mathrm{cm}^{3}\right]$ & 1.371 \\
\hline 間隙比 & $e$ & 0.922 \\
\hline 飽和度 & $S_{r}[\%]$ & 15 \\
\hline
\end{tabular}

表-6 室内・降雨条件

\begin{tabular}{|c|c|c|}
\hline \multirow{2}{*}{ 降雨実験室 } & 気温 $\left[{ }^{\circ} \mathrm{C}\right]$ & 6.0 \\
\hline & 湿度 [\%] & 90 \\
\hline \multirow{2}{*}{ 降雨 } & 水温 $\left[{ }^{\circ} \mathrm{C}\right]$ & 8.0 \\
\hline & 強度［mm/hour] & 50 \\
\hline
\end{tabular}

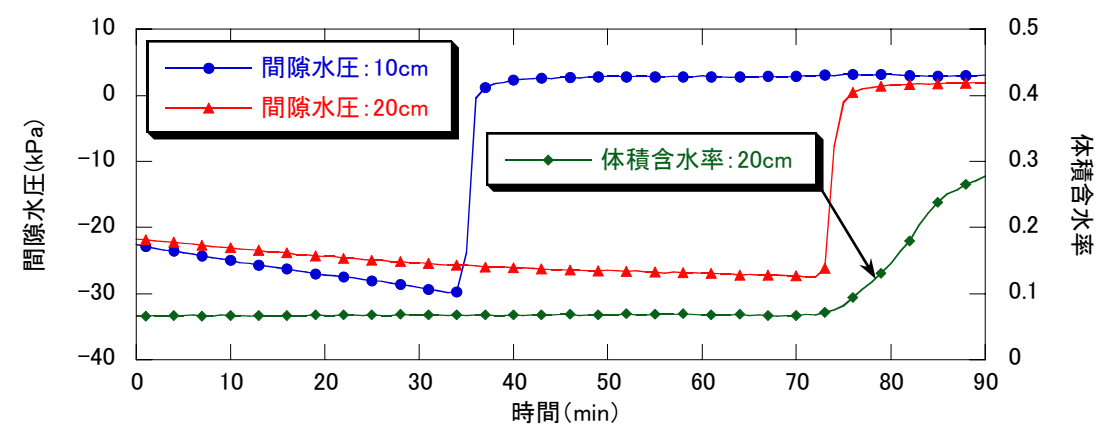

図-19 間隙水圧，体積含水率の時系列変化（試験結果）

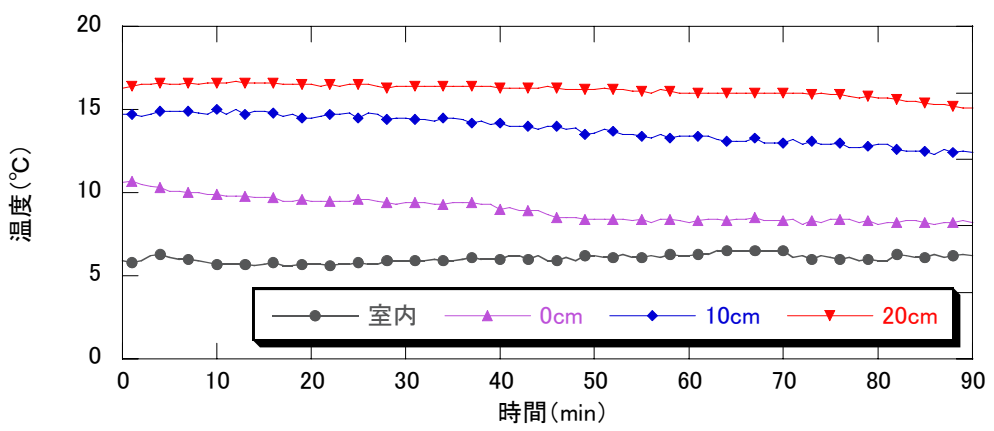

図-20 室内および地中温度の時系列変化（試験結果） 
なってから深さ $10 \mathrm{~cm}$ の地中温度も大きく低下し, 深さ $20 \mathrm{~cm}$ の温度も同様の傾向を示した。この結果より，土 粒子から水への顕熱の輸送現象が生じており, 地盤内水 分の変動と地中温度の変化に関連性があると考えられる. ここで，フーリエ則（式(16)参照）および計測深度が深 くなるほど温度が高くなっている状況を考慮すると，地 表面から地盤内への熱移動はほとんどない可能性があり， 本試験の温度変化は熱伝導よりも水分移動の影響を受け たと解釈される．したがって，提案手法による地中温度 の計測結果を使って水分変動を評価できると考えられる.

\section{（2）試験結果と計算結果の比較検討}

本論文では，深さ $10 \mathrm{~cm}$ の間隙水圧を比較・検討の対 象とし，以下，図-12 の評価フローに基づいて述べる.

\section{a) 地中温度の推定, 移動平均による算定結果}

表-7 は計算に使用する条件と得られた空間増分 $\Delta z$ で あり，図-21 は単純移動平均を使って地中温度を平均化 した結果を示している.

\section{b) 熱拡散係数の算定結果}

図-22 は熱拡散係数の算出結果である.この結果より， 熱拡散係数が試験開始 35 分〜 40 分で大きく変化してお り，深さ $10 \mathrm{~cm}$ の間隙水圧が大きく変化した時間帯（図一 19 参照）とほぼ一致している。つまり, 地中温度と地 盤内水分の変化は連動している可能性がある. しかし, 試験開始から 45 分後以降は深さ $10 \mathrm{~cm}$ の地盤内水分はほ ぼ飽和状態にあるにもかかわらず，熱拡散係数が減少す る（地盤内水分が乾燥傾向に移行する）結果となった. そこで，地中温度の変化傾向に注目して，この原因につ いて検討する. 図-23に経過時間に対する深さ $10 \mathrm{~cm} の$ 温度差を示す. この温度差はセンサ精度の範囲内（士 $\left.0.5^{\circ} \mathrm{C}\right)$ であるため, 計測誤差の可能性が考えられる.

しかし, 図-23 の囲み部分より, 雨水の浸透によって温 度差は小さくなっていることが確認できるため, 図-23 の囲み部分は熱拡散係数が減少した時間帯であると解釈 できる。また，熱拡散係数を算出する式(4)の分子は 「経過時間に対する温度変化」を表すため, 熱拡散係数 の算定結果は温度変化の影響を直接受けると考えられる. したがって，熱拡散係数が減少したのは，経過時間に対 する温度変化がなくなったためであると結論付けられる.

\section{c）地盤内の水分変動評価}

熱拡散係数の計算結果と「熱一水分特性曲線」を使っ て体積含水率を求めた結果を図-24, 間隙水圧を求めた 結果を図-25 に示す. はじめに，体積含水率の結果につ いて検討する. 図-24 中の試験結果は, 深さ $10 \mathrm{~cm}$ の間 隙水圧の計測結果を van Genuchten モデル式（式(10)参 照）で体積含水率に変換したもので，このモデル式に用 いたパラメータは表-4 と同様である。試験結果と計算
表-7 計算に使用する条件, 空間増分 $\Delta z$

\begin{tabular}{c|c}
\hline$\Delta t[\mathrm{~min}]$ & 5 \\
\hline$a_{\max }\left[\mathrm{m}^{2} / \mathrm{sec}\right]$ & $4.048 \times 10^{-7}$ \\
\hline$a_{\min }\left[\mathrm{m}^{2} / \mathrm{sec}\right]$ & $1.667 \times 10^{-7}$ \\
\hline$\Delta z[\mathrm{~m}]$ & 0.0128 \\
\hline
\end{tabular}

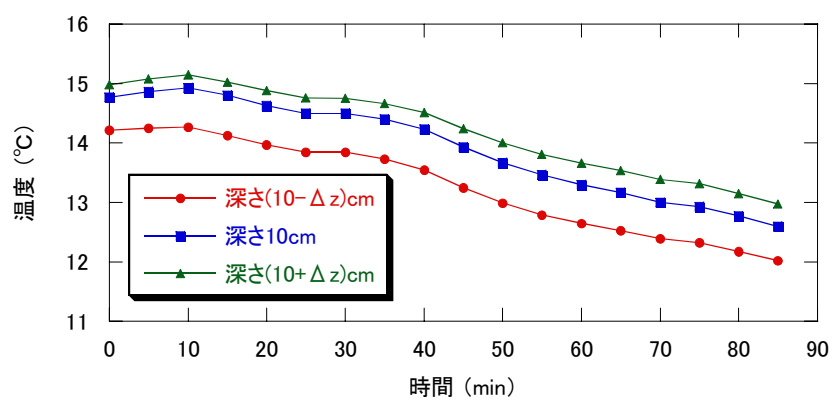

図-21 単純移動平均による地中温度の算定結果

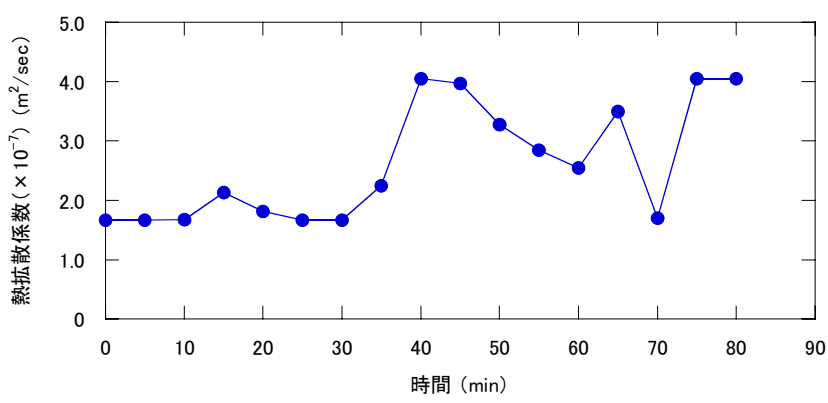

図-22 熱拡散係数の計算結果

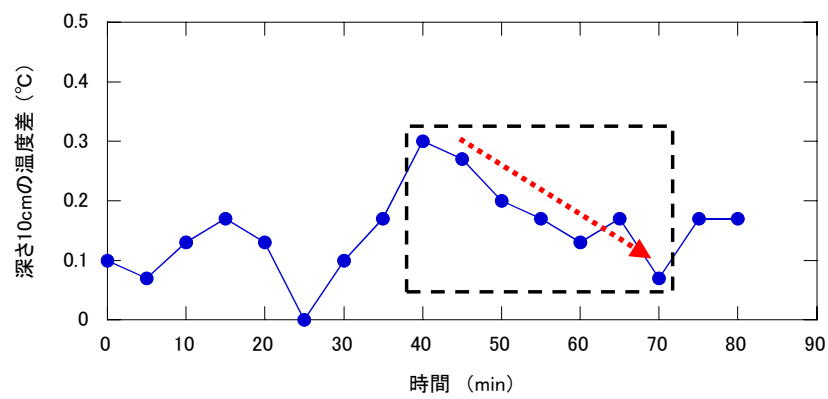

図-23 経過時間に対する深さ $10 \mathrm{~cm}$ の温度差

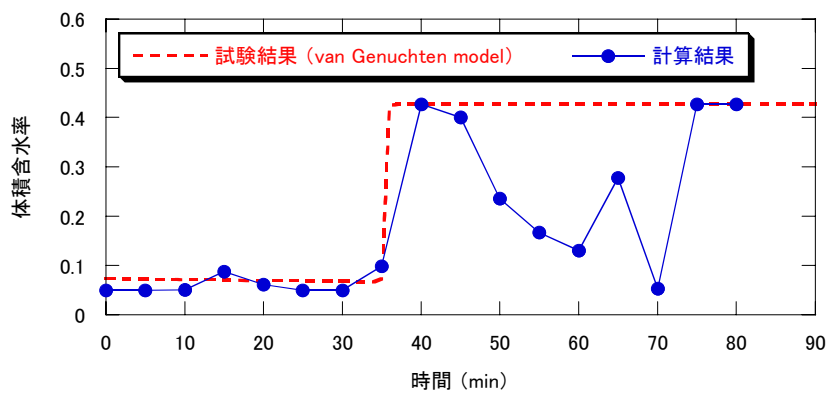

図-24 体積含水率の試験結果, 計算結果

結果を比較すると，体積含水率が大きく変化した時間帯 と值はほとんど一致しているものの, 降雨開始から40 


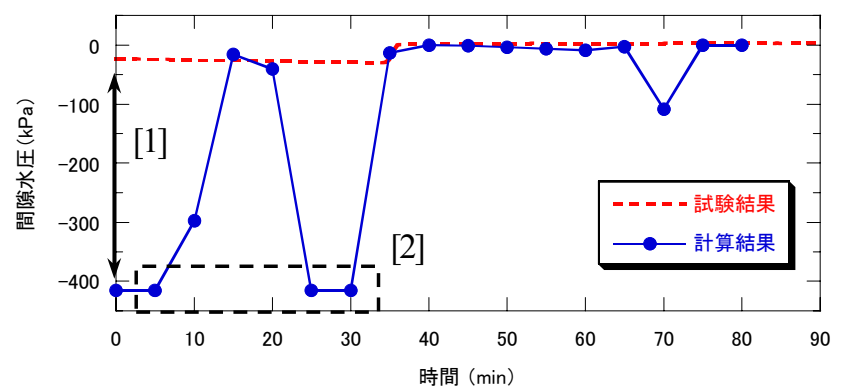

図-25＼cjkstart間隙水圧の試験結果，計算結果

分後にはほぼ飽和状態になったにもかかわらず計算結果 は低下している.ここで, 提案手法（理論式）に基づい て計算結果に対する原因と提案手法の適用範囲を検討す る. 前項の「b) 熱拡散係数の算定結果」で述べたよう に，式(4)を使って熱拡散係数を求めるとき，式(4)の分 子である「経過時間に対する温度変化」が 0 になると熱 拡散係数は 0 となるため, 式(8)や式(11)の「熱拡散係数 ～体積含水率・圧力水頭」より地盤内水分は乾燥状態を 示す。つまり, 地盤内の水分状態が飽和の場合でも経過 時間に対する温度変化が 0 になると, 乾燥状態として地 盤内の水分変動を評価することとなる，つまり，深さ $10 \mathrm{~cm}$ の間隙水圧が急増した後のほぼ一定に推移する挙 動を提案手法による計算結果で表現できなかったのは, 経過時間に対する温度変化がほとんど 0 に近い状態であ ったためと考えられる，以上より，提案手法は経過時間 に対する温度変化が 0 にならない条件で適用することが できると判断される.

次に, 間隙水圧の結果について検討寸る. 図-25 より, 計算結果は降雨開始から 35〜40 分後に大きく変化する という傾向は試験結果に似ているが，初期值（図-25 の [1]）や降雨開始から 35 分までの值（図-25 の[2]）が大 きく異なっている. これは，体積含水率と間隙水圧の関 係である「土の水分特性」が計算結果に影響を与えてい ると予想され，水分特性曲線に注目する. 図-26の囲み 部分の乾燥領域では，体積含水率の変化に対して間隙水 圧は大きく変化するため, 体積含水率から間隙水圧を算 出すると誤差が生じやすい，つまり，温度変化から計算 した熱拡散係数を使って水分変動を評価する場合は，体 積含水率を使うほうが望ましいと考えられる。

\section{6. 室内土槽試験 II}

本試験は，雨水が斜面に浸透した場合における提案手 法の有効性について検証するために実施する．図-27 は モデル土槽の概要であり, 計測機器は熱電対（深さ：10, $20,30 \mathrm{~cm}$ ），テンシオメータ（深さ：20, 40,60cm）を使

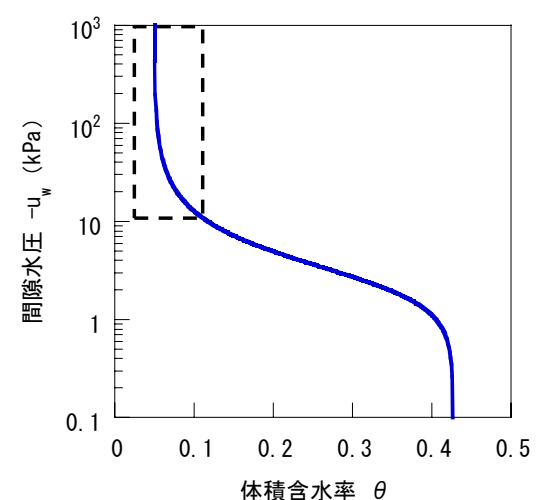

図-26 水分特性曲線

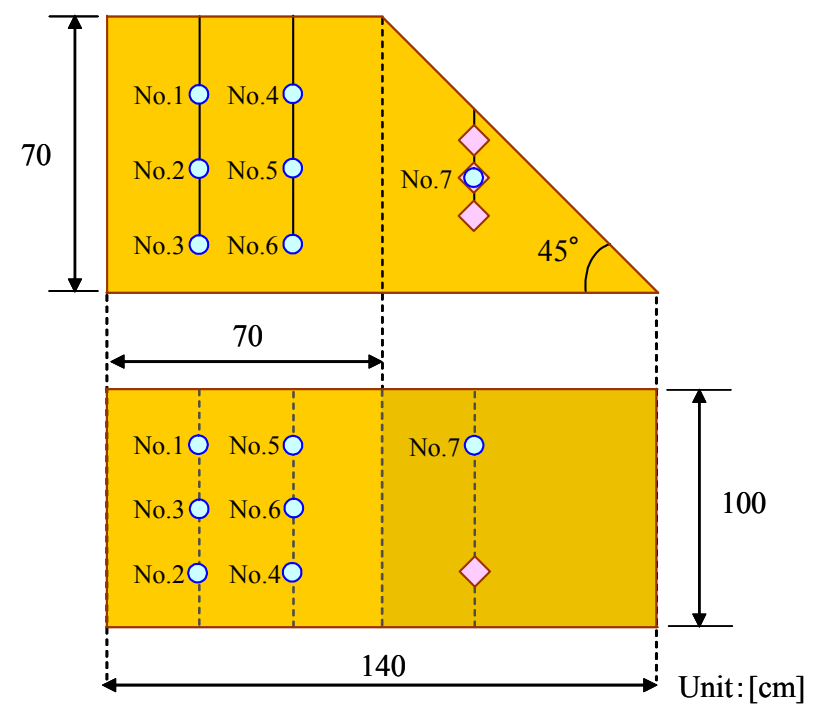

○ : テンシオメータ

(No.1, 4, $7:$ 深さ20cm, No.2, $5:$ 深さ $40 \mathrm{~cm}, \quad$ No.3, $6:$ 深さ $60 \mathrm{~cm}$ ) : 熱電対 (深さ: $10,20,30 \mathrm{~cm}$ )

図-27 モデル土槽の概要

表-8 試験条件

\begin{tabular}{ll|c}
\hline 土粒子密度 & $\rho_{s}\left[\mathrm{~g} / \mathrm{cm}^{3}\right]$ & 2.628 \\
\hline 乾燥密度 & $\rho_{d}\left[\mathrm{~g} / \mathrm{cm}^{3}\right]$ & 1.524 \\
\hline 間隙比 & $e$ & 0.725 \\
\hline 飽和度 & $S_{r}[\%]$ & 18.1 \\
\hline
\end{tabular}

表-9 境界条件および室内・降雨条件

\begin{tabular}{c|c|c}
\hline \multirow{2}{*}{ 境界条件 } & 上面, 斜面 & 注水 \\
\cline { 2 - 3 } & 背面, 底面 & 非排水 \\
\hline 降雨実験室 & 湿度 [\%] & 90 \\
\hline \multirow{2}{*}{ 降雨 } & 水温 [ $\left.{ }^{\circ} \mathrm{C}\right]$ & 8.5 \\
\cline { 2 - 3 } & 強度 $[\mathrm{mm} /$ hour] & 50 \\
\hline
\end{tabular}

用し，設置位置を図-27 に示寸．計測間隔は 1 分とし， 試験終了は盛土が大きく崩壊してから 1 時間後とした. 
試験条件を表-8，境界条件および室内・降雨条件を表-9 に示す.

\section{(1) 試験結果}

図-28 は No.1〜No.3（深さ 20, 40, 60cm）の間隙水圧の 変化を，図-29 は No.4〜No.6（深さ 20, 40,60cm） と No.7

(深さ $20 \mathrm{~cm})$ の間隙水圧の変化を, 図-30 は室内温度と 各深さの地中温度の変化を表しており, 降雨浸透による 地盤内の水分変動, 熱伝導と水分移動による地中温度の 変化 (熱輸送) について考察する.

\section{a）降雨浸透による地盤内の水分変動}

図-28，図-29 の計測結果より，計測機器の設置場所 の違いにほとんど影響することなく各深さの間隙水圧は ほぼ同じ時間帯に大きく変化したが，深さ $60 \mathrm{~cm}$ の間隙 水圧は深さ $40 \mathrm{~cm}$ が変化してからすぐに増加し始めてい る. この現象に関して写真-1 に示す浸潤面の位置から 判断すると，上面からの浸透ではなく斜面側からの浸透 によるものと推測される，また，間隙水圧が大きく変化 して一定值（約-1.5kPa 付近）が続いた後に崩壊したこと から，降雨による斜面崩壊を予知するためには地盤内の 水分変動を直接把握することは重要であると考えられる.

一方, 図-28, 図-29 の結果より, 本試験の初期の含 水比 $(5.0 \%)$ は「5. 室内土槽試験 I : 5.4\%」とほぼ同值 であるにもかかわらず，各深さの初期值に違いが見られ る.また，「No.2-40cm, No.4-20cm」の值は他と異な り試験開始から低下している。しかし，テンシオメータ は試験開始から約 18 時間前に設置し，間隙水圧の值が 落ち着いてから雨を降らせており，初期值の相違や間隙 水圧の低下に対する原因は，現時点では明らかになって いない.

\section{b）熱伝導と水分移動による温度変化（熱輸送）}

初めに，各深さの温度変化について考察する. 深さ $10 \mathrm{~cm}$ の温度は試験開始から上昇し最後は水温に近づい た. 深さ $10 \mathrm{~cm}$ の温度が上昇したのは，室温は深さ $10 \mathrm{~cm}$ の温度よりも高いことを考慮すると，地表面からの熱伝 導が影響したものであり，水温に近づいたのは土粒子か ら水への顕熱の輸送現象が生じた結果であると推測され る. 一方, 深さ $20 \mathrm{~cm}$ は試験開始約 50 分後から上昇し始 め, 最終的に水温に近づいた。温度が上昇し始めた時間 は，深さ $20 \mathrm{~cm}$ の間隙水圧が大きく変化したときとほと んど同じであり，深さ $20 \mathrm{~cm}$ の温度は深さ $10 \mathrm{~cm}$ よりも 低いことを考慮すると，熱と水分の同時移動によるもの ではないかと考えられる，深さ $30 \mathrm{~cm}$ の温度変化につい ては，深さ $20 \mathrm{~cm}$ の場合と同様の変化傾向を示したこと から，熱と水分の同時移動が影響したものと解釈する.

次に, 崩壊前の地中温度変化について考察する. 写 真-2 より, 試験開始から約 300 分後に法先から崩壊し

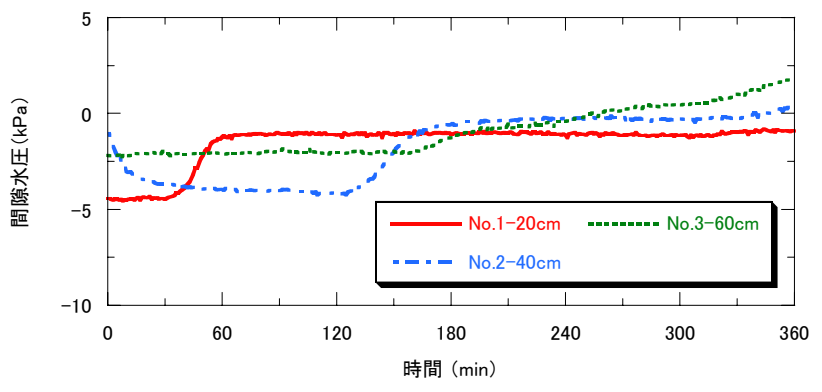

図-28 No.1〜No.3の閒隙水圧の時系列変化（試験結果）

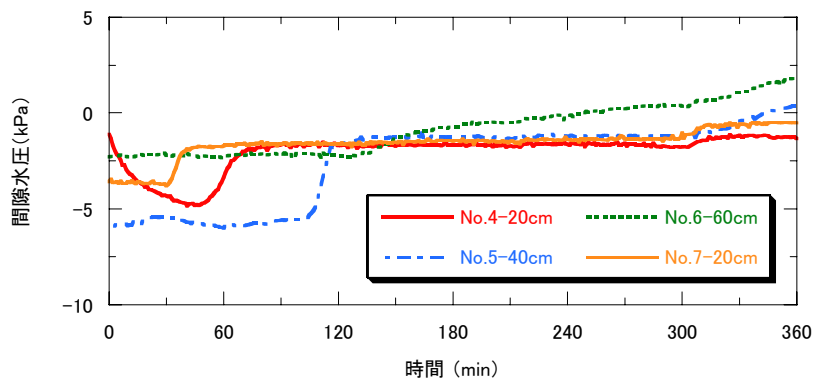

図-29 No.4〜No.7 の間隙水圧の時系列変化（試験結果）

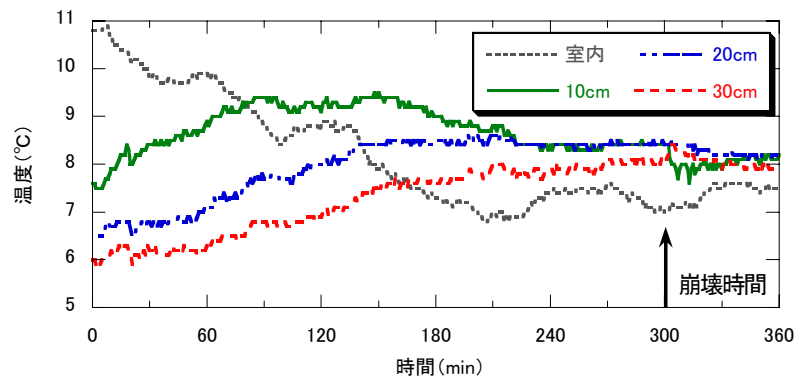

図-30 室内および地中温度の時系列変化（試験結果）

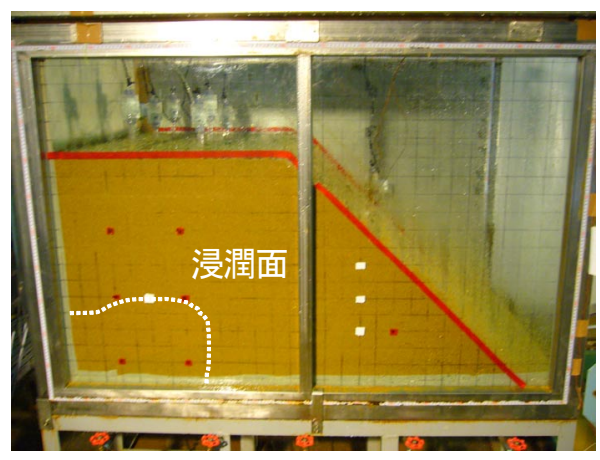

写真-1 降雨開始加 180 分後

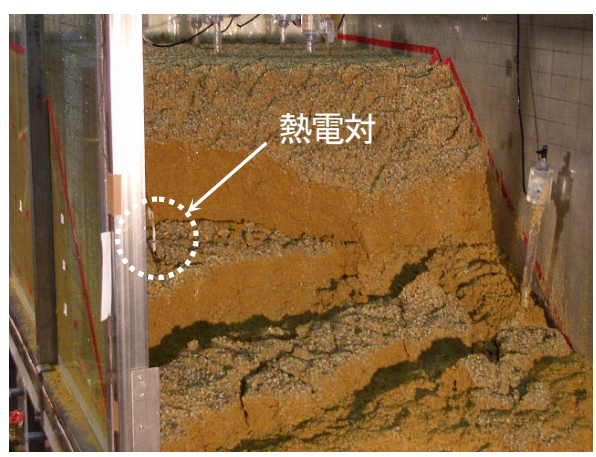

写真-2 降雨開始から 300 分後 
表-10 設定パラメータ

\begin{tabular}{|c|c|c|}
\hline 乾燥密度 & $\rho_{d}\left[\mathrm{~g} / \mathrm{cm}^{3}\right]$ & 1.524 \\
\hline \multirow{3}{*}{$\begin{array}{c}\text { 密度 } \\
{\left[\mathrm{g} / \mathrm{cm}^{3}\right]}\end{array}$} & 土粒子 $\rho_{s}$ & 2.628 \\
\hline & $\rho_{w}$ & 1.000 \\
\hline & 空気 $\rho_{a}$ & 0.001293 \\
\hline \multirow{3}{*}{$\begin{array}{c}\text { 質量比熱 } \\
{[\mathrm{kJ} /(\mathrm{kg} \cdot \mathrm{K})]}\end{array}$} & 土粒子 $c_{s}$ & 0.84 \\
\hline & 水 & 4.18 \\
\hline & 空気 $c_{a}$ & 1.00 \\
\hline \multirow{2}{*}{$\begin{array}{c}\theta \sim k \\
\text { (近似直線) }\end{array}$} & 傾き $\beta$ & 2.5506 \\
\hline & 切片 $\gamma$ & 0.0995 \\
\hline \multicolumn{2}{|c|}{ 残留体積含水率 $\theta_{r}$} & 0.0486 \\
\hline \multicolumn{2}{|c|}{ 飽和体積含水率 $\theta_{s}$} & 0.3822 \\
\hline \multirow{2}{*}{$\begin{array}{c}\text { スケーリング } \\
\text { パラメータ }\end{array}$} & $n$ & 2.4055 \\
\hline & $\alpha[1 / \mathrm{cm}]$ & 0.0354 \\
\hline \multicolumn{2}{|l|}{ 飽和透水係数 } & $3.19 \times 10^{-3}$ \\
\hline
\end{tabular}

表-11 計算に使用する条件，空間増分 $\Delta z$

\begin{tabular}{|c|c|}
\hline$\Delta t \quad(\min )$ & 5 \\
\hline$a_{\max }\left(\mathrm{m}^{2} / \mathrm{sec}\right)$ & $3.733 \times 10^{-7}$ \\
\hline$a_{\min }\left(\mathrm{m}^{2} / \mathrm{sec}\right)$ & $1.511 \times 10^{-7}$ \\
\hline$\Delta z \quad(\mathrm{~m})$ & 0.0122 \\
\hline
\end{tabular}

始め，その後進行性の崩壊が続いた．崩壊する前は間隙 水圧の変化傾向と同じように，深さ $10,20 \mathrm{~cm}$ の温度は約 80 分間一定の挙動を示した. 今回の現象に基づくと, 降雨に対する斜面崩壊を予知寸るためには，地中温度の 変化傾向に注目寸ることも意義があると推測される.

\section{（2）試験結果と計算結果の比較検討}

本論文では，「No.7-20cm」の間隙水圧を比較対象と する．今回の計算で使用する設定パラメータを表-10 に, 熱拡散係数の計算に使う条件と得られた空間増分 $\Delta z$ を 表-11 に示す.

\section{a) 熱拡散係数の算定結果}

図-31 に熱拡散係数の算出結果を示寸。この結果より， 熱拡散係数は試験開始 40 分から 55 分にかけて大きく変 化しており，図-29 の「No.7-20cm」の間隙水圧が大き く変化した時間帯とほぼ一致していることが分かる.し かし，図-31 の[1]〜 [3]（降雨開始直後，試験開始から 85 分後, 150 分後以降) で，熱拡散係数が大きく低下して いる.この原因を 5. (2) b)項で述べた「経過時間に対す る温度差」に注目すると，図-32 の[1]〜[3]に示すように， 降雨開始直後では温度差は大きく，試験開始 85 分

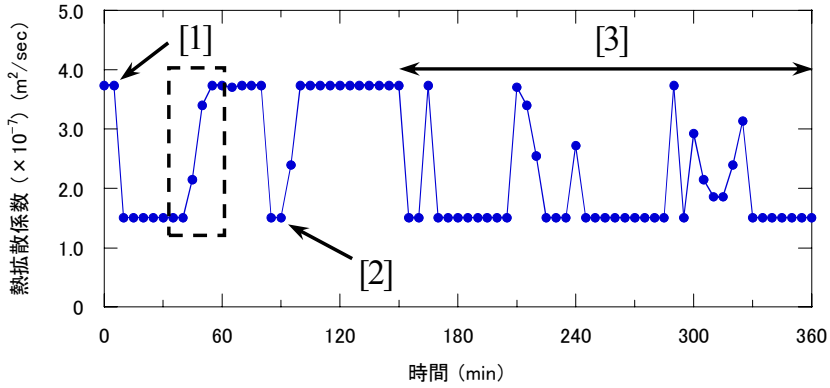

図-31 熱拡散係数の時系列変化 (No.7-20cm)

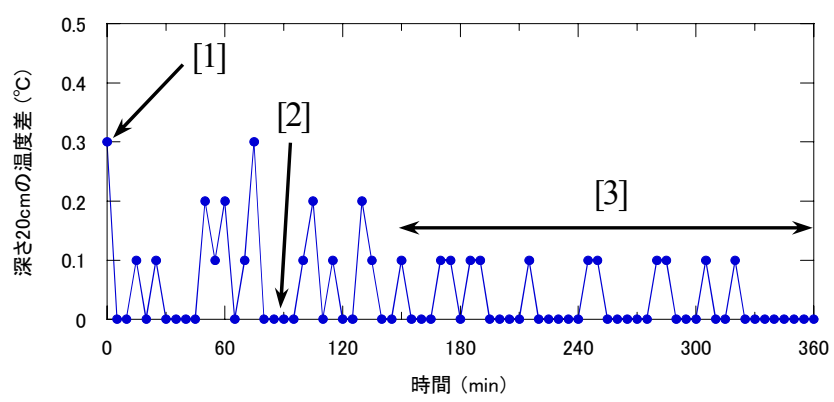

図-32＼cjkstart経過時間に対する温度差（No.7-20cm）

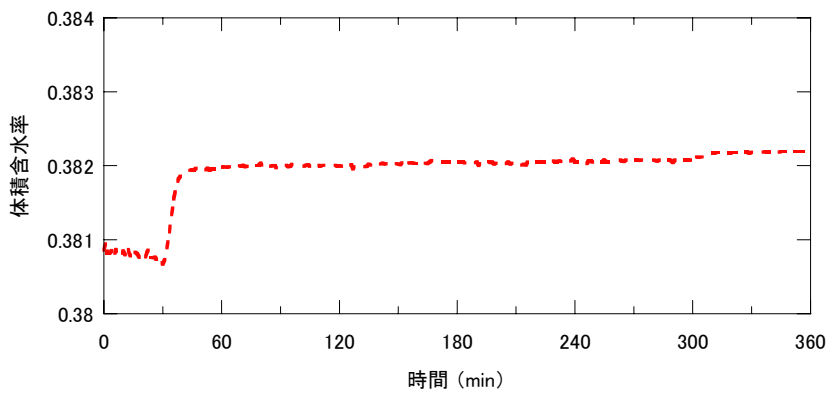

図-33 vanGenuchtenモデル式による体積含水率の推定結果

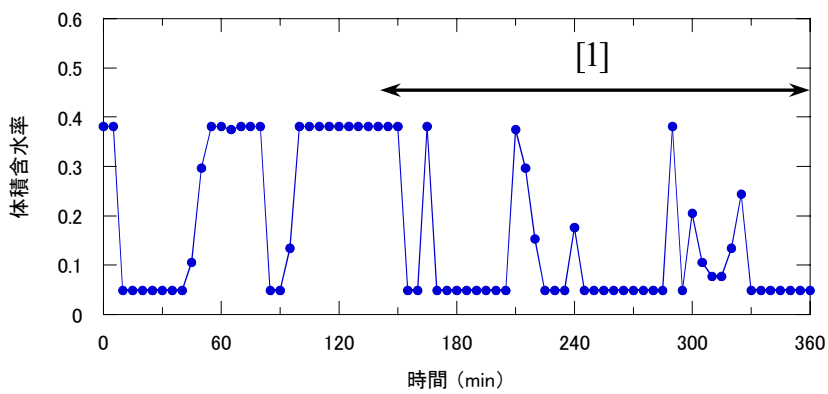

図-34 体積含水率の計算結果

後, 150 分後以降では温度差が小さくなっており,この 温度差が熱拡散係数の計算結果に直接影響を与えたと考 えられる。また，試験開始から 150 分後以降の熱拡散係 数の変動に関しては, 図-32 の[3]より雨水の浸透によっ て温度変化がほとんどなくなった結果が反映している.

\section{b）地盤内の水分変動評価}

熱拡散係数から算定した体積含水率を試験結果と比較 する，試験結果を図-33，計算結果を図-34 に示す。な お，試験結果とは van Genuchten モデル式 (式(10), 表-10 
参照）を使って間隙水圧の計測結果から体積含水率を推 定したものである. 試験結果および計算結果より，初期 の体積含水率の值は大きく異なっているものの, 大きく 変化したときの時間帯と值はほぼ一致している，值が異 なっているのは，モデル土槽作製時に調整したときの含 水条件（含水比 : $5.0 \%$, 体積含水率 : 0.076 ）之試験開始 時の含水状態（体積含水率：0.381）が異なったためで あると推測され，この点に関しては 5. (1)節でも述べて いる. また, 図-34 の[1]において, 体積含水率が大きく 変化した後は図-32 の[3]のように温度変化が小さくなる ことから, 飽和した後の地盤内の水分変動を評価するこ とは容易ではないと考えられる.この挙動に対する原因 と提案手法の適用範囲は 5. (2) c) 項でも述べている. し かし, 温度計 (熱電対) を深さ方向に対して多地点に設 置することで, 温度変化をより詳しく把握できるため, 現時点でどの地点が飽和しているかを段階的に把握でき るものと推測される.

なお，本試験のように提案手法を使って間隙水圧や体 積含水率を推定した場合の算定誤差が大きいことは事実 である. しかし, 本論文では地中温度と地盤内の水分変 動の関係を明確にし，その関係に基づいて地中温度から 水分変動を簡易に評価できる可能性を示すことに重点を 置いている. 今後は, 計測機器の設置位置や精度などを 向上し提案手法を改良することで, 計算結果の誤差は小 さくなると考えられる.

\section{（3）提案手法の現地適用に関する一考察}

本節では, 室内土槽試験における提案手法の妥当性に 関する検証結果をもとに，提案手法を現地（自然斜面や 河川堤防など）に適用した際の評価範囲（深さ）につい て，文献と現地計測結果を用いて考察する.

文献 13)によると，地表面温度の振幅を $20^{\circ} \mathrm{C}$ とた場 合, 深さ $60 \sim 70 \mathrm{~cm}$ までは日変化の影響を受け, 深さ $70 \mathrm{~cm}$ よりも深い地点が評価対象である場合は，地下水 の流動が影響して地中温度が変化した結果が報告されて いる. また, 植生の影響として, 裸地と林地における気 温と地中温度の計測結果も示されており, 裸地よりも林 地のほうが地中温度の変化率が小さく温度が変化する深 度も浅い部分であることから，現地の環境によって熱の 伝播特性は異なると解釈される.

次に, 京都市東山山麓周辺の現地斜面（図-35, 写真3 参照) で計測した結果 (間隙水圧, 地中温度, 降雨量 (時間雨量，連続雨量））を図-36 に示寸，なお，時間 雨量は直近の 60 分間に降った雨量とし, 連続雨量は降 り始めから降り終わりまでの一連の降雨量の積算值であ る. 間隙水圧を計測するためのテンシオメータは深さ 20, 40, 60, 80, 100cm，地中温度を計測するための熱電対

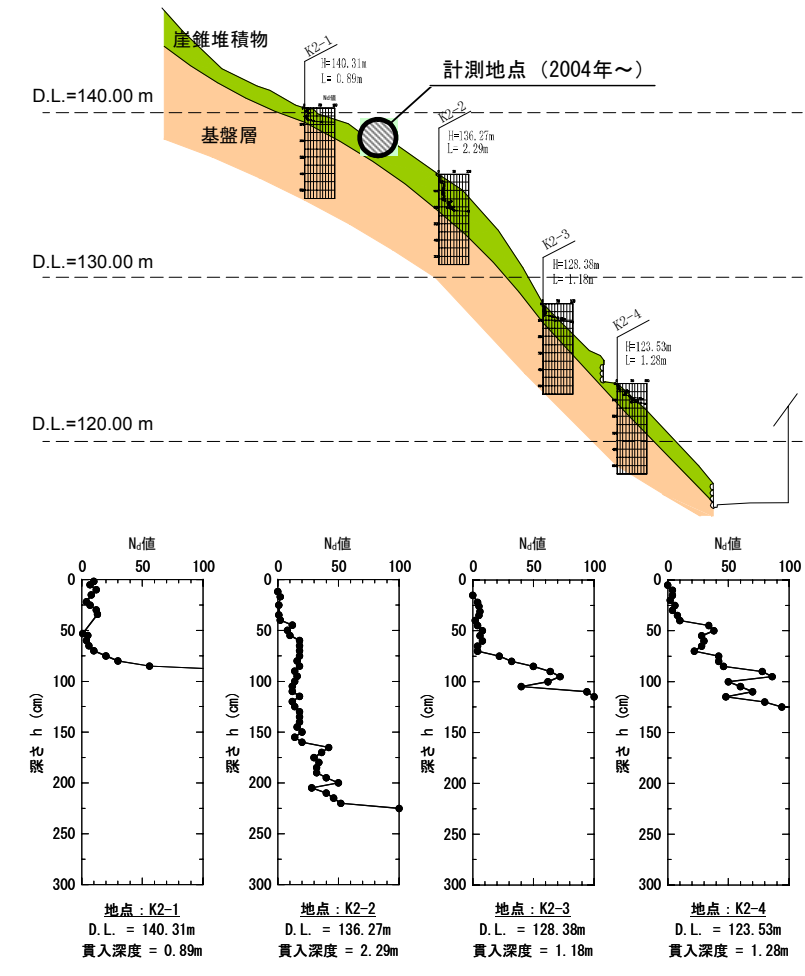

図-35 対象斜面の地質断面図と計測地点

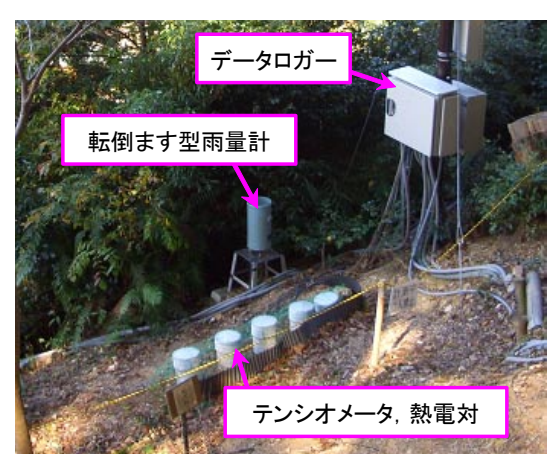

写真-3 計測地点の設置状況
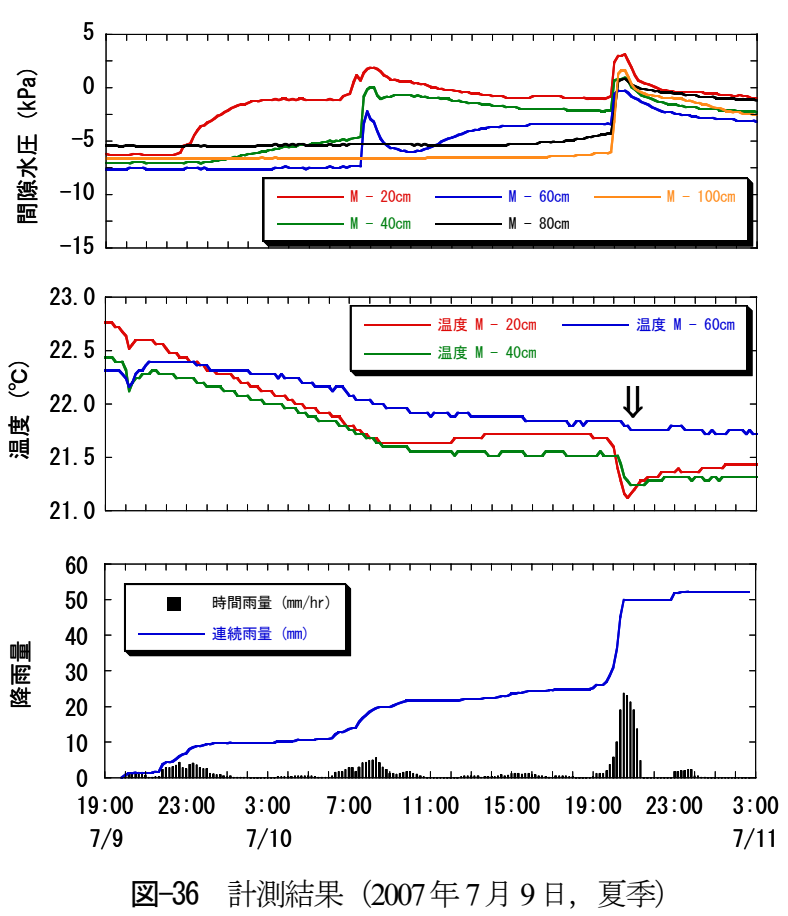
（精度 : $\pm 1.0^{\circ} \mathrm{C}$, 測定温度の $\pm 0.75 \%$ ）は深さ 20,40 , $60 \mathrm{~cm}$ に設置している. ここでは，降雨に対する間隙水 圧と地中温度の変化傾向について検討するため，年間を 通して気温の変化が最も明瞭な夏季の計測結果（2007 年 7 月 9 日）を一例とする. 図-36 の矢印 (ل) に注目 すると, 深さ $20,40 \mathrm{~cm}$ の間隙水圧が急増するとともに温 度が大きく低下していることから，この温度変化は水分 移動によるものと推測され，土粒子から水への顕熱輸送 であると解釈される.

このように，地盤内を雨水が浸透する過程を把握する 際, 地中温度の変化傾向に注目することも意義があると 考えられ，提案手法は現地に適用できる可能性がある. また，提案手法は熱源を必要とせず地中温度の計測結果 のみを使用した方法であるため, 計測機器のメンテナン スの軽減や設置コストの削減に期待できるのではないか と考えられる.

\section{7. まとめ}

本研究では，地中温度の変化と地盤内の水分変動の関 係に注目し，熱源を使わず温度変化のみで地盤内の水分 変動を評価する方法を新たに提案し「熱一水分特性曲 線」を定式化した. 提案手法の有効性を検証するために 降雨による室内土槽試験を行い，試験結果と計算結果を 比較・検討した. 本研究によって得られた知見（室内土 槽試験，提案手法）を以下に述べる.

\section{（1）室内土橝試験}

（1）熱伝導による室内モデル試験結果より，土の水分量 と熱伝導率の関係は正の相関をもち，土における熱 の伝播特性は水分量の影響を受けることが分かった。

(2) 降雨による円筒力ラム試験では, 雨水の浸透に伴っ て地中温度は低下した結果より，土粒子から水への 顕熱の輸送現象が生じていることが推定できた.

(3) 降雨による盛土試験結果より，土粒子から水への顕 熱の輸送現象が生じたこと，熱と水分の同時移動に よって地中温度が変化したことを推定できた.

(4) 降雨による盛土試験より, 間隙水圧や地中温度が変 化して一定值が続いた後に崩壊したことから，降雨 による斜面崩壊を予知するためには間隙水圧や地中 温度の変化傾向を直接把握することが重要である.

\section{(2) 提案手法}

(1) 地中温度の計測間隔を 5 分に設定すると, 計測デー タの乱れを抑えることができた，また，単純移動平 均を使ってデータを整理すると, 地中温度の変化傾
向を連続的に把握できることが分かった。

(2) 提案手法は温度変化のみから水分変動を簡易に評価 する手法であるため，熱移動の基礎方程式には水や 空気のフラックスによる影響を考慮していない. し かし，地盤内水分が急増したときの時間帯と值では 試験結果と良い整合性を示すことが検証できた.

(3) 試験結果で地盤内水分が急増した後の挙動を提案手 法で表現できなかった原因について理論（提案手 法）をもとに検討した結果，経過時間に対して温度 変化がない状態（熱拡散係数が 0) では，提案手法 は適用できない可能性が大きいことが推測できた。

つまり，提案手法は経過時間に対する温度変化が 0 にならない範用で適用できると解釈した。

(4) 提案手法を使って地盤内の水分変動を評価する際, 体積含水率と間隙水圧の関係「土の水分特性」が計 算結果に影響を与えるため，採用する評価変数には 間隙水圧よりも体積含水率のほうが望ましいことが 分かった.

(5) 提案手法の現地適用については, 文献と現地斜面の 計測結果より, 温度変化が 0 でなければ適用できる 可能性があることが推定できた.

このように，地中温度計測による本手法は適用範囲 (経過時間に対して温度変化がある状態) は限られるも のの, 地盤内の水分が急増したときの挙動を簡易に評価 することができる. 従来の方法と比べても, テンシオメ 一タ法における脱気水の補給やヒートプローブ法におけ る計測時の熱源の使用などという固有の問題が少ない点 で優れていると判断できる.

今回の知見 (室内土槽試験, 提案手法) をもとに今後 の課題を以下に示し，さらに研究を進める予定である.

(1) 提案手法において「土の水分量と熱伝導率の関係」 を把握し定式化することは重要であるため, 土の種 類に対する水分量や間隙比を変えた場合の「土の水 分量と熱伝導率の関係」を調べる必要がある.

(2) 本研究では, 地中温度の変化から水分変動を簡易に 評価できる可能性を示すことに重点を置いているた め，土の熱収支である顕熱や潜熱現象は考えていな い.今後は熱収支を考慮した評価方法を検討する必 要がある.

(3) 提案手法では地盤内水分が大きく変化した後の挙動 （值がほぼ一定を推移する挙動）を表現できなかっ たため,この挙動を評価できるような方法を提案し， 室内土槽試験で改良した評価手法の妥当性を検証す る必要がある。また, 提案手法は地中温度の計測結 果の影響を直接受けるため, 計算結果の誤差を小さ くする方法（例えば，計測機器の設置位置や精度な ど）について検討する必要がある. 


\section{参考文献}

1) 岡田憲治 : 土壌雨量指数, 測候時報, 気象庁, 第 69 巻, 5 号, pp.83-84, 2002.

2) Malicki, M. A., Plagge, R. and Roth, C. H.: Improving the Calibration of Dielectric TDR Soil Moisture Determination Taking into Account the Solid Soil, European J. Soil Sci., Vol.47, pp.357-366, 1996.

3) 粕淵辰昭: 土壌肥料研究における新しい分析手法 2, 熱電動 式土壤水分計, 日本土䁃肥料科学雑誌, Vol.63, No.3, pp.359-363, 1992.

4) 藤縄克之 : 飽和多孔体中の 2 相系熱伝導に関する実験的研 究一多孔体中の熱移動に関する研究(II)一, 農業土木学会論 文集, Vol.154,p.118, 1991.

5) Woodside, W., Messmer, J. H.: Thermal Conductivity of Porous Media. I. Unconsolidated Sands, J. Appl. Phys., Vol.32, No.9, 1961.

6) De Vries, D. A.: Thermal Properties of Soils, In : W. R. Van Wijk (Ed), Physics of Plant Environment, North-Holland Publishing Co., pp.214-218, 1963.

7) 粕淵辰昭 : 土壌の熱伝導におよぼす水分の影響, 日本土䁃 肥料学䧱誌, Vol.43, No.12,pp.437-441, 1972.
8) Van Wijk, W. R., De Vries, D. A.: Periodic Temperature Variations In A Homogeneous Soil, In : Van Wijk, W. R. (Ed), Physics of Plant Environment, North-Holland Publishing Co.,pp.108-114, 1963.

9) van Genuchten, M. Th.: A closed-form equation for predicting the hydraulic conductivity of unsaturated soil, Soil. Sci. Soc. Am. J., Vol.44, pp.892-898, 1980.

10) Mualem, Y.: A new model for predicting the hydraulic conductivity of unsaturated porous media, Water Resour. Res., Vol.12, pp.513-522, 1976.

11) Šimůnek, J., Šejna, M., and van Genuchten, M.Th.: The HYDRUS-2D software package for simulating two-dimensional movement of water, heat, and multiple solutes in variably saturated media. Version 2.0. IGWMC-TPS-53. Int. Ground Water Modeling Ctr., Colorado School of Mines, Golden, 1999.

12）日本熱物性学会 : 熱物性ハンドブック,p.488, 1990.

13) 竹内篤雄 : 温度測定による流動地下水調査法, p.87, pp.117118, 古今書院, 1996.

(2008.1.23 受付)

\section{A NEW METHOD FOR EVALUATING WATER BEHAVIOR IN UNSATURATED SOIL BASED ON GROUND TEMPERATURE MEASUREMENT RESULTS}

\section{Tomoaki SATOMI, Kazunari SAKO, Ikuo YASUKAWA and Ryoichi FUKAGAWA}

In this paper, we focus our attention on relationship between water behavior in soil and variation of ground temperature due to rainfall and solar radiation. A new method was proposed to evaluate the water behavior in unsaturated soil based on the ground temperature measurement results. The modeling test for seepage behavior was also conducted to validate the proposed model. Results obtained from this paper show that using this approach, a new relationship that described the status of "Heat-Soil moisture characteristic curve" can be found. By using the developed technique, the time and the value when porewater pressure was increased greatly was in good agreement with experiment. 